\title{
ARTÍCULOS
}

\section{LA EMIGRACIÓN ESPAÑOLA A AMÉRICA EN LA ÉPOCA MODERNA. UN ACERCAMIENTO AL ESTADO DE LA CUESTIÓN.}

\author{
Palmira García Hidalgo \\ Universidad de Huelva \\ palmira.garcia@dhga.uhu.es
}

Resumen: La emigración española a América durante el periodo colonial ha sido un fenómeno de gran transcendencia para el discurrir de la historia y las relaciones entre el Viejo y el Nuevo Mundo. Por ello, se ha convirtió en objeto de interés de numerosos investigadores. Este artículo pretende presentar la producción historiográfica realizada en torno a tal cuestión, resaltando cuáles fueron los periodos de mayor auge, las diferentes líneas temáticas abarcadas y la evolución en las metodologías empleadas, así como las fuentes documentales analizadas. Este trabajo se estructura en tres partes: primero referimos las obras que tratan la emigración a la colonia de forma general, posteriormente abordamos aquellas que atienden de forma específica a las mujeres, por considerar la gran transcendencia de estos estudios, y en último lugar, aquellas que conectan la correspondencia privada con las migraciones.

Palabras clave: España, América, investigaciones, emigración, mujeres, correspondencia privada, colonial.

Tittle: EMIGRATION TO AMERICA IN THE MODERN PERIOD. AN INTRODUCTION TO THE STATE OF THE TOPIC.

Abstract: Spanish emigration to America during the colonial era has been a very significant episode in history, having implications in the relationships between the Old and the New World. Therefore, it has been of interest for many researchers. This article aims to introduce the historiographical production originated about the topic. It highlights the periods with the highest peak, the different topics involved, and the evolution of both the methods applied and the analysed sources. This work has been structured in three parts. Firstly, we are going to deal with the works referring to emigration to the colony in general terms. Secondly, we are going to review the ones concerning women, given the relevance and implications of these studies.Thirdly, we are going to approach the works which connect private post with migrations.

Keywords: Spain, America, researches, emigration, women, private post, colonial.

\section{Introducción: el interés de los fenómenos migratorios y los primeros análisis}

El fenómeno de la emigración, que tantos debates está causando en los últimos

Recibido: 31-01-2019

Aceptado: $11-03-2019$

Cómo citar este artículo: GARCÍA HIDALGO, Palmira. La emigración española a América en la época moderna. Un acercamiento al estado de la cuestión. Naveg@mérica. Revista electrónica editada por la Asociación Española de Americanistas [en línea]. 2019, n. 23. Disponible en: <http://revistas.um.es/navegamerica>. [Consulta: Fecha de consulta]. ISSN 1989-211X. 
tiempos, no es algo nuevo, pues en todas las épocas históricas se ha venido produciendo el desplazamiento de la población desde sus lugares de origen a otros países o regiones, en la mayoría de los casos por causas económicas o sociales. La relevancia de estos movimientos, así como su amplia extensión en el tiempo, ha provocado que sean numerosos los investigadores que se han interesado en su análisis.

Ningunos años han sido tan emblemáticos para nuestra historia como los de la colonización americana. Por tal razón, este trabajo se centra en los estudios sobre la emigración española a América durante el periodo colonial - siglos XVI al XVIII-. Se trató de un movimiento de larga duración, sujeto a diferentes coyunturas históricas, y cuyas causas y consecuencias no fueron constantes, variando en función de las circunstancias: crisis en las tierras de origen, posibilidades de mejora en las de acogida, en definitiva, causas o factores de expulsión y de atracción. Como en todos los movimientos relacionados con las migraciones.

Para estudiar este fenómeno existen diversos documentos, entre otros, las fuentes indirectas, como las actas de bautismo, matrimonio y defunción localizadas en los archivos parroquiales, las variables demográficas y los protocolos notariales. Muchas de ellas aportan información parcial, pues tan sólo dan testimonio de la partida hacia América, en tanto que poco o nada anuncian de su llegada: aún no han sido muy tratados documentos que aporten noticias importantes en este sentido. Esta ausencia ya fue resaltada por un clásico de los estudios migratorios, Magnus Mörner en 1975:

“¿Qué hay sobre el material de fuentes relativo a la llegada los emigrantes al Nuevo Mundo? Estas son sorprendentemente escasas, a pesar de las reales órdenes de mediados del siglo XVI, que disponían que debían llevarse registros de pasajeros e inmigrantes que desembarcaran en las colonias"1.

No obstante, debemos indicar que en la actualidad tenemos constancia de la existencia de determinados fondos documentales en algunas ciudades americanas lo que permitiría aumentar el acercamiento a los desplazados españoles instalados en aquellas tierras. Entre estos podríamos destacar: los padrones, las primeras relaciones de vecinos, los primeros registros parroquiales post-tridentinos, registros de defunción y sepultura y la información existente en los archivos de determinadas congregaciones religiosas ${ }^{2}$.

Las fuentes imprescindibles, y las más utilizadas desde los inicios de las investigaciones sobre este tema, son las custodiadas en el Archivo General de Indias de Sevilla (en adelante AGI), destacando las denominadas "licencias de embarque", que aportan gran cantidad de datos sobre los emigrantes. Sin embargo, presentan un inconveniente: por lógica, y siendo documentación exigida para el viaje, solo muestran el tránsito legal; queda por saber qué porcentajes marcharían

\footnotetext{
${ }^{1}$ MÖRNER, Magnus. La emigración española al Nuevo Mundo antes de 1810: un informe del estado de la Investigación. Anuario de Estudios Americanos.1975, n. 32, pp. 43-131.

${ }_{2}^{2}$ La existencia de registros parroquiales en Hispanoamérica es bastante temprana, buena muestra de ello es este reciente trabajo: LATASSA LATASA, Pilar. Matrimonios clandestinos y matrimonios secretos (DCH). Max Planck Institute for European Legal History Research Paper Series. 2019, n. 11.
} 
ilegalmente. No obstante, también se han realizado análisis sobre este tipo de migraciones haciendo uso de otra modalidad de documentación, como veremos más adelante. Se trata de las fuentes complementarias, incorporadas a este tipo de trabajos, como la correspondencia privada, los expedientes de bienes de difuntos, así como alguna documentación notarial, y determinados censos de población.

Aclararemos que las primeras investigaciones se centraron en determinar las causas que motivaron este desplazamiento de larga distancia, discutiendo las ventajas e inconvenientes que ocasionaron al país, y cuáles fueron las líneas de la política migratoria. En un primer momento destacaron los estudios cuantitativos y de carácter general, que aportaron datos sobre el sexo, la edad, los grupos profesionales, lugares de origen y destino, etc., de los emigrantes a América. A medida que nos adentramos en la última década del siglo $\mathrm{XX}$, comenzaron a tomar importancia los de carácter cualitativo, así como regionales, y aparecieron nuevos temas como, por ejemplo, las formas de vida, el trasvase de libros o la correspondencia privada.

En medio de tantos documentos y análisis cuantitativos y cualitativos, hemos de mencionar que no proliferaron los textos sobre el papel de las mujeres; bien es verdad que sí contamos con algunos, centrados en los años iniciales de la conquista, en las leyes que regulaban su paso a Indias o en su función dentro de la sociedad colonial, siendo muy escasas las aproximaciones al género femenino en relación con el flujo migratorio.

Si nos atenemos al tiempo estudiado, hemos de destacar, en primer lugar, que los siglos que más atención han recibido por parte de los investigadores han sido el $\mathrm{XVI}$ y XVIII, este último en menor medida y no en los textos iniciales. Las mayores lagunas corresponden al siglo XVII, existiendo únicamente menciones parciales en ejemplares de carácter general hasta que comenzaron a desarrollarse algunos trabajos regionales o con temáticas muy concretas. No obstante, destacan, en número, los ejemplares que analizan el fenómeno migratorio de forma global: desde su descubrimiento y colonización hasta la independencia, presentando una visión general del proceso.

Las primeras publicaciones sobre el paso de españoles al continente americano comenzaron a ver la luz a finales del siglo XIX, pero dicha materia no tuvo relevancia dentro de las investigaciones históricas hasta la mitad de la centuria siguiente. Hubo que esperar a la última década del siglo XX para ver un mayor interés por parte de los estudiosos, manifiesto en el aumento de las ediciones, sobre todo tras el impulso de la celebración del V Centenario del Descubrimiento de América. En su mayoría, aparecieron entre los años 1990-2000; a partir de entonces el interés empezó a decaer, si bien continuaron editándose algunos textos aislados.

Para desarrollar el presente artículo hemos localizado, a través de diferentes bibliotecas y repositorios, trabajos existentes sobre la materia que nos ocupa a fin de realizar su análisis y conocer su evolución, los métodos empleados, los documentos examinados y las líneas temáticas abarcadas, así como sus principales expertos. Considerando los límites de este tipo de publicaciones, primaremos autores y obras 
de mayor transcendencia. Por cuestiones metodológicas, la bibliografía existente ha sido clasificada en tres epígrafes, dos de ellos atendiendo al objeto principal de estudio -si se trata de emigración a América de forma general o si atienden específicamente a las mujeres- y el tercero según la fuente analizada -emigración y correspondencia privada-.

\section{Evolución de las investigaciones sobre emigración española a América durante la época colonial}

Los trabajos iniciales sobre migración trataron movimientos contemporáneos a la conquista y colonización; como ejemplo, los textos de V. Aubrey Neasham (1939), Ciríaco Pérez Bustamante (1941), Juan Friede (1951, 1952,1966), Mario Góngora (1962), James Lockhart (1968), y los de Ángel Rosenblat (1971) ${ }^{3}$. Estas obras centraron su atención en el origen geográfico de los emigrantes y conquistadores, así como en sus perfiles sociales. Muchos de ellos constituyeron análisis basados en menciones encontradas en ejemplares de carácter general y no en un estudio exhaustivo de fuentes primarias. Salvo las de Ciriaco Pérez Bustamante, Mario Góngora y Juan Friede, se trataba de investigaciones llevadas a cabo por filólogos, razón por la cual primó el estudio del idioma español en América sobre el propio fenómeno migratorio.

Aunque más escasos, no podemos dejar de mencionar la existencia de algunos que analizaron el fenómeno, bien de forma general, bien deteniéndose en tiempos concretos y más avanzados de la colonización. Así, Luisa Cuesta Gutiérrez (1932), que estudió la emigración gallega a América durante todo el periodo, aporta una información centrada sobre todo en el siglo XVIII, al basarse en los fondos de la Biblioteca América de la Universidad de Santiago de Compostela; Vicente Borregón Ribes (1952) analizó el fenómeno migratorio atendiendo a sus causas, dificultades planteadas y a los problemas propios del viaje, dejando de lado la metodología cuantitativa ${ }^{4}$.

Para la realización de muchas de estas investigaciones fue de gran importancia el comienzo, en el año 1940, de un importante proyecto promovido por el AGl consistente en publicar un Catálogo de Pasajeros a Indias. Esta iniciativa se paralizó

\footnotetext{
${ }^{3}$ NEASHAM, V. Aubrey. Spain's Emigrants to the New World 1492-1592. The Hispanic American Historical Review. 1939, vol. 19, n. 2, pp. 147-160; PÉREZ BUSTAMANTE, Ciriaco. Las regiones españolas y la población de América (1509-1534). Revista de Indias. 1941, n. 6, pp. 81-120; FRIEDE, Juan. The "Catalogo de Pasajeros" and Spanish Emigration to America to 1550. The Hispanic American Historical Review. 1951, n. 31, pp. 331-348; FRIEDE, Juan. Algunas observaciones sobre la realidad de la emigración española a América en la primera mitad del siglo XVI. Revista de Indias. 1952, n. 49, pp. 472-473; FRIEDE, Juan. Los estamentos sociales en España y su contribución a la emigración en América. Revista de Indias. 1966, n. 103-104, pp. 13-30; GONGORA, Mario. Los grupos de conquistadores en Tierra Firme (1509-1530). Fisonomía histórico-social de un tipo de conquista. Santiago de Chile: Centro de Historia Social, Universidad de Chile, 1962; LOCKHART, James. Spanish Peru, 1532-1560: A Colonial Society. Madison: The University of Wisconsin Press, 1968; ROSENBLAT, Ángel. Base del español de América: Nivel social y cultural de los conquistadores y pobladores. Revista de Indias. 1971, vol. XXXI, n. 125-126, pp. 13-75.

${ }^{4}$ CUESTA GUTIÉRREZ, Luisa. La emigración gallega a América. Santiago: Nos Publicacions galegas e Imp., 1932; BORREGÓN RIVES, Vicente. La emigración española a América. Vigo: Imprenta Faro de Vigo, 1952.
} 
en el año 1946, habiéndose editado hasta el momento tres volúmenes, siendo retomada unas décadas después, hasta la aparición en 1980 del séptimo tomo; cronológicamente abarcan hasta el año $1599^{5}$. A día de hoy quedan sin ver la luz los años restantes del periodo colonial, pero por suerte la mayor parte de la información se encuentra disponible en la red, concretamente en el Portal de Archivos Españoles.

Mención especial merecen los importantes estudios de Peter Boyd-Bowman $(1963,1967,1976)$, el primero en realizar un examen sistemático y pormenorizado de las fuentes para conseguir resultados reales y no simples conjeturas. Este autor fundamentó sus obras en los Libros de Asientos de Pasajeros y en los Expedientes de Informaciones y Licencias, y estableció el modelo general de la emigración de españoles al continente americano durante el siglo XVI, aportando importantes datos sobre su composición social, origen geográfico, y otros muchos aspectos. Sus conclusiones fueron básicas y asumidas en las décadas siguientes por los historiadores interesados en el tema, convirtiéndose en un referente ${ }^{6}$.

Según se observa, a lo largo de estas décadas asistimos a una diversificación y multiplicación de fuentes primarias; ejemplo de ello fueron los trabajos de Guillermo Lohmann Villena (1958), investigador reconocido cuyos estudios se basaron en los expedientes de bienes de difuntos de los emigrados a Perú; por los mismos años, José Castro Seoane (1960) analizó los libros de contratación para conocer a los misioneros que pasaron a tierras americanas; Jorge Ignacio Rubio Mañé (1966) centró sus estudios en el padrón de 1689 de la Ciudad de México, a fin de determinar el número de españoles residentes en ella; y David Brading (1973), en la misma línea que el anterior, estudió los orígenes provinciales de los emigrantes de México a través del uso de un censo anual de $1792^{7}$. Los dos últimos suponen un buen ejemplo de aproximaciones a los emigrados peninsulares con documentos localizados al otro lado del Océano. Todos ellos aportaban una información mayoritariamente cuantitativa, cuyo interés estaba centrado en conocer la dimensión numérica del fenómeno. En esta misma línea, pero con datos cualitativos, debemos mencionar los textos de Susan Socolow, basado en una rica documentación de archivos americanos, como testamentos, dotes, papeles del Consulado y archivos parroquiales de Buenos Aires, entre otros, y del ya mencionado David Brading, sobre

\footnotetext{
${ }^{5}$ Catálogo de Pasajeros a Indias durante los siglos XVI, XVII y XVIII. Sevilla: Imprenta editorial de la Gavidia, 1940-1980.

${ }^{6}$ BOYD-BOWMAN, Peter. La emigración Peninsular a América: 1520 a 1539. Historia Mexicana. 1963, vol. 13, n. 2, pp. 165-192; BOYD-BOWMAN, Peter. La procedencia de los españoles de América: 1540 - 1559. Historia Mexicana. 1967, vol. 17, n. 1, pp. 37-71; BOYD-BOWMAN, Peter. Pattersn of Spanish immigration to the Indies until 1600. Hispanic American Historical Review. 1976, n. 56, pp. 580-604; Algo más avanzado en el tiempo, pero de gran relevancia fue su obra Índice geobiográfico de más de 56 mil pobladores de la América Hispánica. México D.F.: Fondo de Cultura Económica, 1985.

${ }^{7}$ LOHMANN VILLENA, Guillermo. Índice de los expedientes de bienes de difuntos en el Perú. Revista del Instituto peruano de investigaciones genealógicas. 1958, vol. XI, n. 11, pp. 58-133; CASTRO SEOANE, José. Aviamiento y catálogo de las misiones que en el siglo XVI pasaron de España a Indias y Filipinas según los libros de la contratación. Madrid: Raycar, S.A. Impresores, 1960; RUBIO MAÑÉ, Jorge Ignacio. Gente de España en la ciudad de México año de 1689. México: Archivo General de la Nación, 1966; BRADING, David. Los españoles en México hacia 1792. Historia Mexicana. Jul./Sep. 1973, vol. XXIII, n. 1, pp. 126-144.
} 
mineros y comerciantes en el México borbónico sustentado en distintos registros notariales de archivos mexicanos ${ }^{8}$.

El año de 1975 fue clave en la evolución de los estudios migratorios. Es el año en el que Magnus Mörner publicó el primer estado de la cuestión; en él nos informaba de la existencia de algunas publicaciones, resaltando dos cuestiones: primera, que sólo se había estudiado una pequeña parte de toda la documentación existente y segunda, que casi todo el interés había sido enfocado en el siglo XVI, siendo muy escasas las referencias a las centurias posteriores. Señaló, además, el carácter general y aproximativo de las conclusiones de los textos editados. Como es bien sabido, nos hallamos ante un artículo de gran trascendencia para los análisis posteriores. De igual impacto sería su segundo y más importante estado de la cuestión, publicado en 1991, convertido en un texto de referencia; más adelante volveremos a ello ${ }^{9}$.

A partir de este momento se fue produciendo un aumento del interés por el campo de estudio que nos ocupa, especialmente en España; un interés reflejado en el desarrollo de importantes congresos, jornadas y seminarios, en los que quedó patente el carácter regional adquirido por las investigaciones, comenzándose a vislumbrar la necesidad de coordinación de estos trabajos para adquirir resultados globales. Tuvieron gran relevancia los Coloquios de Historia Canario-Americana y las Jornadas de Andalucía y América. Canarias fue el primer lugar en el que se comenzaron a realizar reuniones regulares, relacionadas con la investigación del fenómeno migratorio, y de las conexiones con América. Tales coloquios fueron impulsados por Francisco Morales Padrón e iniciados en 1976; todas sus actas han sido publicadas, aportando múltiples temas como los referentes a la política emigratoria, los bienes de difuntos de los fallecidos en Indias, la esclavitud, o el negocio azucarero. Dado el elevado número de autores remitimos al lector a las ediciones correspondientes ${ }^{10}$.

Como Canarias, Andalucía. Aquí las Jornadas comenzaron a desarrollarse a partir de 1981, bajo el nombre citado de Jornadas de Andalucía y América y organizadas y editadas por distintas instituciones, destacando la Escuela de Estudios Hispano-Americanos de Sevilla y la Diputación Provincial de Huelva. En ellas participaron a lo largo de los años autores de gran relevancia como Lourdes Díaz-Trechuelo, Juan Marchena, Juana Gil-Bermejo, e Isabelo Macías, con contribuciones centradas en la emigración andaluza a las Indias ${ }^{11}$; a destacar en

\footnotetext{
${ }^{8}$ MIGDEN SOCOLOW, Susan. The merchants of Buenos Aires 1778-1810. Family and commerce. Cambridge University Press, 1978; BRADING, David. Mineros y comerciantes en el México borbónico (1763-1810). Madrid: FCE, 1975; De semejantes características es el trabajo publicado algunos años después por KICZA, John. Empresarios coloniales: familias y negocios en la ciudad de México durante los Borbones. Madrid: FCE, 1983.

9 MÖRNER, Magnus. La emigración española. Op. cit.; MÖRNER, Magnus. Migraciones a Hispanoamérica durante la época colonial. Suplemento de Anuario de Estudios Americanos. 1991, vol. 48, n. 2, pp. 3-26.

${ }^{10}$ En la actualidad aún se siguen desarrollando. La última en otoño de 2018, celebrado en Las Palmas de Gran Canaria.

${ }^{11}$ DÍAZ-TRECHUELO, Lourdes. Emigración cordobesa a las Indias: siglo XVI. En: AA. VV. Primeras Jornadas de Andalucía y América: La Rábida. Diputación Provincial de Huelva; Instituto de Estudios Onubenses. 1981, vol. 1, pp. 405-426; MARCHENA FERNÁNDEZ, Juan. La emigración andaluza en
} 
todas ellas las conexiones entre Andalucía y el continente americano durante el periodo colonial.

Las conferencias presentadas en las jornadas mencionadas continuaron dedicando especial atención a la cuantificación de las personas que cruzaron al otro lado del Océano -pese a que algunas atendiesen otras materias-, así como a los aspectos legales; en ellas también se aprecia la ya referida multiplicación de las fuentes documentales empleadas. En cuanto a la dimensión espacial abarcada, se vislumbra una importante regionalización, lo que supone la ausencia de datos generales.

En las investigaciones regionales, no hemos de olvidar el análisis de otros espacios: la zona norte peninsular fue tratada en el libro Santander y el Nuevo Mundo (1979), en tanto que otros textos debidos a un equipo de historiadores de la Universidad de Córdoba, entre los cuales se encontraba Lourdes Díaz-Trechuelo y Antonio García-Abásolo, vieron la luz en el Congreso Internacional de Historia de América celebrado en el año 1988. Otro libro importante, de carácter más general y con aportaciones a los estudios sobre migraciones, fue América y la España del siglo XVI (1982), coordinado por Francisco Solano y Fermín del Pino Díaz: su contenido era muy variado, incluyendo asuntos como el éxodo eclesiástico o los alistamientos en las Armadas, por mencionar algunos ${ }^{12}$. Últimamente alguna aportación ha vuelto a incidir en el tema ${ }^{13}$. En general, a pesar de tratarse de análisis de zonas muy concretas detallan datos interesantes al atender a contenidos muy diversos, no primando el interés cuantitativo como venía ocurriendo, aunque este si

el ejército de América. En: Primeras Jornadas de Andalucía y América: La Rábida. Diputación Provincial de Huelva, Instituto de Estudios Onubenses. 1981, vol. 1, pp. 461-462; GIL-BERMEJO GARCÍA, Juana y PÉREZ-MALLAÍNA BUENO, Pablo Emilio. Los andaluces en la navegación transatlántica: la vida y la muerte en la Carrera de Indias a comienzos del siglo XVIII. En: TORRES RAMÍREZ, Bibiano y HÉRNADEZ PALOMO, José Jesús (coords.). Andalucía y América en el siglo XVIII: actas de las IV Jornadas de Andalucía y América. Vol. I. Consejo Superior de Investigaciones Científicas, 1985, pp. 271-296; MACÍAS DOMÍNGUEZ, Isabelo. La emigración de Málaga y Jaén hacia América y Filipinas en el siglo XVII. En: TORRES RAMÍREZ, Bibiano y HÉRNADEZ PALOMO, José Jesús (coord.). Andalucía y América en el siglo XVIII. Op. cit.,, pp. 1-28. El listado es mucho más amplio, pero hemos querido mencionar algunos ejemplos. Los trabajos presentados fueron posteriormente publicados en Actas y tuvieron una gran impronta.

${ }^{2}$ CAMUS, Matilde (ed.). Santander y el Nuevo Mundo. Santander: Centro de Estudios Montañeses, 1979; DÍAZ-TRECHUELO, Lourdes y GARCÍA-ABASOLO, Antonio. Córdoba en la emigración andaluza al Nuevo Mundo en la primera mitad del siglo XVII. En: AA. VV. Actas del Congreso Internacional de Historia de América (Córdoba). Vol. II. Córdoba: Consejería de Cultura de la Junta de Andalucía; Monte de Piedad; Caja de Ahorros de Córdoba, 1988, pp. 53-74; DUEÑAS OLMO, Antonio y GARRIDO ARANDA, Antonio. La emigración cordobesa a Indias en la segunda mitad del siglo XVII. En: AA. VV. Actas del Congreso Internacional de Historia de América (Córdoba). Op. cit., pp. 75-92; SOLANO PÉREZ-LILA, Francisco de Paula y PINO DÍAZ, Fermín del (coords.). América y la España del siglo XVI. Madrid: Consejo Superior de Investigaciones Científicas, 1982; BORGES MORÁN, Pedro. La emigración de eclesiásticos a América en el siglo XVI. Criterios para su estudio. En: SOLANO PÉREZ-LILA, Francisco de Paula y DEL PINO DÍAZ, Fermín (coord.). América y la España del siglo XVI. Op. cit., pp. 47-62; PULIDO BUENO, Idelfonso. Algunas notas sobre alistamientos de vecinos de Huelva en las Armadas de Indias a fines del siglo XVI. En: SOLANO PÉREZ-LILA, Francisco de Paula y PINO DÍAZ, Fermín del (coord.). América y la España del siglo XVI. Madrid: Consejo Superior de Investigaciones Científicas, 1982, pp. 147-159.

13 HERNÁNDEZ GONZÁLEZ, Manuel. Al margen de la Corona. La emigración del clero regular canario a América en la Edad Moderna. Tenerife: Ediciones Idea, 2018. . 
siguiera presente en algunos de los textos.

Asimismo, en la década de los ochenta tuvo lugar un hito relevante en el proceso de estudios migratorios: la fundación en Colombres (Asturias) del Archivo de Indianos (1987). Su finalidad: la recuperación y el estudio de documentación relacionada con la emigración asturiana y española a América. Si bien es cierto que prima el análisis de los siglos posteriores a la colonización, no lo es menos que no se excluyen tomos referentes al periodo de dominación española, aunque en un número mucho menor.

En este lapso de tiempo también debemos reseñar la aparición de la revista Estudios Migratorios Latinoamericanos, editada por el centro de estudios del mismo nombre, en Buenos Aires (1985); está especializada en migraciones hacia, desde y dentro del continente americano, y trata diversos temas en relación con la materia desde una perspectiva interdisciplinar ${ }^{14}$.

A fines de dicho decenio, los preparativos para la celebración del V Centenario del Descubrimiento de América supusieron un impulso a las investigaciones. Muestra de ello fue la gran cantidad de publicaciones surgidas entre los años 1989 y 1995. Una de las primeras manifestaciones fue la edición de la Revista Da Comisión Galega do Quinto Centenario (1989-1990) en la que figuraron algunos trabajos de interés sobre emigración. A destacar los de Antonio Eiras, Rosario Márquez, Ofelia Rey, Ricardo Turnes, Enrique Martínez y Domingo González ${ }^{15}$. El espacio geográfico cubierto se limitó a Galicia; sin embargo, las materias expuestas fueron diversas.

Continuando con esta tendencia, la década de los noventa asistió a la aparición de importantes publicaciones, tanto colectivas como individuales. En tales años, la historiografía sobre las migraciones había experimentado un importante avance; se habían alcanzado algunos éxitos, sobre todo a nivel regional; habían emergido nuevas fuentes documentales, como es el caso de la correspondencia privada, y tratado aspectos inéditos; la evolución presentaba entonces un panorama diferente: desde los primeros estudios, interesados en analizar las tendencias generales y en cuantificar el fenómeno migratorio, hasta análisis de carácter cualitativo volcados en otros aspectos. Pero, pese a los progresos mencionados, no se había realizado ninguna revisión de las conclusiones e hipótesis asentadas, manteniéndose las cifras ofrecidas en las clásicas obras, ya citadas, de Peter Boyd-Bowman y Magnus

\footnotetext{
14 Estudios Migratorios Latinoamericanos. Buenos Aires: Centro de Estudios Migratorios Latinoamericanos, 1985-actualmente.

${ }^{15}$ EIRAS ROEL, Antonio. Sobre las motivaciones de la emigración gallega a América y otros aspectos. Un enfoque comparativo. Revista da Comisión Galega do Quinto Centenario. 1989, n. 2, pp. 57-72; MÁRQUEZ MACÍAS, Rosario. La emigración gallega a América en la época del comercio libre (1765-1824). Revista da Comisión Galega do Quinto Centenario. 1989, n. 4, pp. 172-182; REY CASTELAO, Ofelia y TURNES MENJUTO, Ricardo. La emigración a América en la cuenca media del Ulla: un ejemplo de análisis comarcal. Revista da Comisión Galega do Quinto Centenario. 1989, n. 4, pp. 177-222; MARTíNEZ RODRÍGUEZ, Enrique. La emigración a América desde la ciudad de Santiago en la época preestadística: problemas de fuentes y resultados. Revista da Comisión Galega do Quinto Centenario. 1990, n. 6, pp. 31-48; GONZÁLEZ LOPO, Domingo. Una aproximación a la emigración de Galicia occidental entre mediados del siglo XVII y el primer tercio del XX a través de las fuentes de protocolos y archivos parroquiales. Revista da Comisión Galega do Quinto Centenario. 1990, n. 6, pp. 135-169.
} 
Mörner, quién también puso de manifiesto todas estas cuestiones en su segundo estado de la cuestión ${ }^{16}$.

Entre los volúmenes colectivos apuntados, hemos de destacar los siguientes: El libro La emigración española a Ultramar, 1492-1914 (1991) que congrega las Actas de la I Reunión Científica de la Asociación de Historia Moderna, celebrada en 1989; en el se abordaba el tema desde distintas perspectivas, atendiendo asuntos tales como el precio y las condiciones de los pasajes a Indias, o el carácter familiar, dominante en la emigración de determinadas zonas, por poner algún ejemplo. Encontramos asimismo trabajos regionales (según zonas administrativas actuales), hallándose presentes los tres siglos coloniales, si bien unos en mayor medida que otros $^{17}$. También fueron recopiladas y publicadas las Actas del II Congreso de la Asociación de Demografía Histórica, correspondientes al celebrado en Alicante el año de 1990, cuyo primer volumen llevó el título Emigración española y portuguesa a América ${ }^{18}$.

En lo concerniente a estas obras globales no podemos olvidar el libro La emigración andaluza a América. Siglos XVI y XVIII (1991), coordinado por Lourdes Díaz-Trechuelo: un importante avance en el conocimiento del fenómeno migratorio andaluz, que sentaría las bases para futuros trabajos de línea semejante. Consistía en un análisis cuantitativo, usando como fuente principal los Libros de Asientos de Pasajeros, así como algunas licencias de embarque, aunque solo atendieron a los pobladores, quedando excluidos los mercaderes y eclesiásticos ${ }^{19}$.

En esta misma línea, en 1992, tuvo lugar la publicación de una de los obras de síntesis más importantes sobre la emigración española, formada por dos volúmenes, titulada Historia General de la Emigración española a Iberoamérica, y coordinada por Pedro A. Vives, Pepa Vega y Jesús Oyamburu. El primero de los tomos aborda el proceso general migratorio con estudios que tratan desde los precedentes, como el de Rosario Márquez y Encarnación Lemus, hasta el contexto socioeconómico de ambos lados del Océano, por Marta Elena Casaús y Jesús Martínez, e incluso su incorporación a la sociedad colonial, de Antonio Miguel Bernal y María del Pilar Cagiao; el segundo se detiene en las distintas aportaciones regionales, participando los máximos especialistas en la materia, como con María del Carmen Martínez, Nuria Tabanera, o las arriba citadas, Rosario Márquez y Encarnación Lemus, por mencionar algunos ${ }^{20}$.

\footnotetext{
${ }^{16}$ MÖRNER, Magnus. Migraciones a Hispanoamérica. Op. cit.

17 EIRAS ROEL, Antonio (coord.). La Emigración española a Ultramar, 1492-1914. Asociación de Historia Moderna: Ediciones Tabapress, 1991; DURÁN LÓPEZ, Gonzalo. Pasajes a Indias a principios del siglo XVIII: precios y condiciones. En: EIRAS ROEL, Antonio (coord.). La Emigración española a Ultramar. Op. cit., pp. 199-214; TESTÓN NÚÑEZ, Isabel; HERNÁNDEZ BERMEJO, María Ángeles y SANTILLANA PÉREZ, Mercedes. El contexto familiar de la emigración extremeña a Indias en el siglo XVI. En: EIRAS ROEL, Antonio (coord.). La Emigración española a Ultramar. Op. cit., pp. 245-256.

${ }^{18}$ GONZÁLVEZ PÉREZ, Vicente [et al.]. (coord.). Emigración española y portuguesa a América. Actas del Il Congreso de la Asociación de Demografía Histórica. Alicante, abril de 1990, vol. 1. Universitat de València, Seminari d"Estudis sobre la Població del País Valencià; Diputación Provincial de Alicante, Instituto Alicantino de Cultura Juan Gil-Albert, 1991.

19 DÍAZ-TRECHUELO, Lourdes (coord.). La emigración andaluza a América. Siglos XVII y XVIII. Sevilla: Consejería de Cultura y Medio Ambiente, D.L. 1991.

${ }^{20}$ VIVES, Pedro A.; VEGA, Pepa y OYAMBURU, Jesús (coord.). Historia general de la emigración
} 
Como quedó citado, en estos años noventa, vieron la luz numerosas obras individuales. Algunas presentan un carácter regional; otras, más general. En el primer grupo, destacan, para el caso extremeño, las investigaciones de Ida Altman, Encarnación Lemus López y Rocío Sánchez Rubio; Antonio Duplá Ansuátegui estudió la presencia vasca; los emigrantes canarios fueron investigados por Antonio Macías Hernández; los asturianos por Rafael Anes Álvarez; los castellano-leoneses fueron tratados por María del Carmen Martínez Martínez; Antonio Eiras Roel y Ofelia Rey Castelao se encargaron de los gallegos; al análisis de Murcia se acercaron Juan Andreo García y Lucía Provencio Garrigós; y Ángela Pereda López se detuvo en la emigración burgalesa ${ }^{21}$. Sus estudios ratificaban, a estas alturas, un uso exhaustivo de fuentes diversas: no sólo los documentos custodiados en el AGI sino también aquellos localizados en los archivos municipales y notariales (testamentos, poderes, documentos de compra-venta, etc.). Además, en algunos de los escritos se puede observar la inclusión de aspectos tanto cualitativos como cuantitativos, hasta entonces tratados de forma asilada.

En el otro grupo destacan cuatro grandes trabajos: Carlos Martínez Shaw publicó La emigración española a América, 1492-1824 (1994), realizando una interesante síntesis de los datos conocidos hasta el momento sobre la emigración a América en la época colonial. Fue una recopilación de las cifras aportadas por los investigadores dedicados al tema como Richard Knotzke, Peter Boyd-Bowman, Magnus Mörner, Lourdes Díaz-Trechuelo, Encarnación Lemus, Juana Gil, Auke Pieter Jacobs o Rosario Márquez, por citar algunos. Su principal interés radica en la reunión de todos los conocimientos sobre el fenómeno existentes hasta la fecha, lo

española a lberoamérica. Madrid: Historia 16, D.L. 1992; LEMUS LÓPEZ, Encarnación y MÁRQUEZ MACÍAS, Rosario. Los precedentes. En: VIVES, Pedro A.; VEGA, Pepa y OYAMBURU, Jesús (coord.). Historia general de la emigración española a lberoamérica. Op. cit., pp. 37-92; CASAÚS ARZÚ, Marta Elena y MARTÍNEZ, Jesús. Planteamiento general del contexto socioeconómico: España e lberoamérica. En: VIVES, Pedro A.; VEGA, Pepa y OYAMBURU, Jesús (coord.). Historia general de la emigración española a lberoamérica. Op. cit., pp. 151-176; BERNAL RODRÍGUEZ, Antonio-Miguel y CAGIAO VILA, María del Pilar. Incorporación al mercado laboral e inserción social. En: VIVES, Pedro A.; VEGA, Pepa y OYAMBURU, Jesús (coord.). Historia general de la emigración española a lberoamérica. Op. cit., pp. 275-330.

${ }^{21}$ Extremadura: ALTMAN, Ida. Emigrantes y sociedad: Extremadura y América en el siglo XVI. Madrid: Alianza Editorial, 1992; LEMUS LÓPEZ, Encarnación. Ausente en Indias: una historia de la emigración extremeña a América. Madrid: Siruela, D.L., 1993; SÁNCHEZ RUBIO, Rocío. La emigración extremeña al Nuevo Mundo: exclusiones voluntarias y forzosas de un pueblo periférico en el siglo XVI. Badajoz: Siruela, D.L. 1993. País Vasco: DUPLÁ ANSUÁTEGUI, Antonio. Presencia vasca en América: 1492- 1992: una mirada crítica. Donostia: Tercera Prensa, D.L. 1992; Canarias: MACÍAS HERNÁNDEZ, Antonio. La emigración canaria, 1550-1980. Gijón: Júcar, 1992; Asturias: ANES ÁLVAREZ, Rafael. La emigración de asturianos a América. Colombres: Fundación Archivo de Indianos, 1993. Castilla y León: MARTíNEZ MARTíNEZ, María del Carmen. La emigración castellanoleonesa al Nuevo Mundo (1517-1700). Junta de Castilla y León, Consejería de Cultura y Turismo, 1993. Galicia: EIRAS ROEL, Antonio y REY CASTELAO, Ofelia. Los gallegos y América. Madrid: Fundación MAPFRE, 1992. Murcia: ANDREO GARCÍA, Juan y PROVENCIO GARRIGÓS, Lucía. Pasajeros a América: aportación al estudio de la emigración del Reino de Murcia durante el S. XVI. Anales de Historia Contemporánea. 1991, n. 8, pp. 97-130. Burgos: PEREDA LÓPEZ, Ángela. La emigración burgalesa a América: durante el siglo XVI. Burgos: Caja de Burgos, 1999.

Estos autores han publicado otras obras abordando la misma temática, pero hemos seleccionado las más relevantes. Así mismo hay otros investigadores que abordan el asunto, pero se han mencionado los de mayor transcendencia. 
que permitió tener una visión más o menos general del proceso ${ }^{22}$.

En segundo lugar, hemos de destacar el libro Los movimientos migratorios entre Castilla e Hispanoamérica durante el Reinado de Felipe III, 1598-1621 (1995), cuyo autor fue Auke Pieter Jacobs. Se trata de un análisis cuantitativo apoyado no sólo en licencias de embarque, añadiendo informaciones procedentes de expedientes de limpieza de sangre, e informes de visitas y pleitos (estos últimos para la emigración clandestina). Nos encontramos ante una contribución revisionista, que puso en duda las cifras aportadas hasta el momento por otros investigadores; estimaba que habían de reducirse, alegando que no debía subestimarse la capacidad que la Corona tuvo para controlar el pase ilegal. Su mayor atractivo fue el de aunar todos los recursos disponibles en el AGI, pues consideraba que hasta la fecha solo habían sido estudiados de forma parcial y fragmentaria ${ }^{23}$.

Al mismo tiempo, aparecía otra obra de gran importancia, debida a Rosario Márquez Macías (1995). Nos hallamos ahora ante un estudio sobre la emigración legal, sin incluir la migración canaria, que tuvo lugar a través del puerto de Cádiz entre 1765-1824, período del que la información conocida era muy escasa. Se examinaban en ella 17.231 licencias de embarque, número más que notable y que permitió obtener datos concretos sobre la marcha legal de españoles al continente americano en el periodo referido ${ }^{24}$. Cuatro años después apareció una publicación de materia semejante centrada en un período anterior: La llamada del Nuevo Mundo: la emigración española a América (1701-1750) debida a Isabelo Macías Domínguez y fundamentada, del mismo modo, en un volumen importante de las fuentes del AGI, profundizando, además, en la distinción del pase legal y el fraudulento $(1999)^{25}$.

Estudios más específicos publicados en los últimos años del siglo XX fueron, entre otros: Inmigrantes clandestinos españoles y extranjeros en Nueva España a finales del siglo XVII, elaborado por María del Carmen Lara Zenón (1994); Los prohibidos en la emigración a América (1492-1550), escrito por Esteban Mira Caballos (1995); y los de Carlos Alberto González Sánchez (1995) y José Miguel Aramburu Zudaire (1999) sobre la distinta fortuna de los emigrantes a Indias ${ }^{26}$. Nos

\footnotetext{
${ }^{22}$ MARTínEZ SHAW, Carlos. La emigración española a América, 1492-1824. Colombres, Asturias: Archivo de Indianos, 1994. Esta obra se enmarca dentro de las publicadas por el proyecto editorial llevado a cabo por el Archivo de Indianos de Colombres promovido como consecuencia de la celebración del $\mathrm{V}$ Centenario del Descubrimiento de América.

${ }_{23}$ JACOBS, Auke Pieter. Los movimientos migratorios entre Castilla e Hispanoamérica durante el Reinado de Felipe III, 1598-1621. Amsterdam: Rodopi, 1995; JACOBS, Auke Pieter. Pasajeros y polizones: algunas observaciones sobre la emigración española a las Indias durante el siglo XVI. Revista de Indias. 1983, vol. 43, n. 172, pp. 439-479.

${ }^{24}$ MÁRQUEZ MACÍAS, Rosario. La emigración española a América, 1765-1824. Oviedo: Universidad de Oviedo, 1995.

${ }^{25}$ MACÍAS DOMÍNGUEZ, Isabelo. La llamada del Nuevo Mundo: la emigración española a América (1701-1750). Sevilla: Universidad de Sevilla, Secretariado de Publicaciones, 1999.

${ }^{26}$ LARA ZERÓN, María del Carmen. Inmigrantes clandestinos españoles y extranjeros en Nueva España a finales del siglo XVII. Temas americanistas. 1994, n. 11, pp. 25-39; MIRA CABALLOS, Esteban. Los prohibidos en la emigración a América (1492-1550). Estudios de historia social y económica de América. 1995, n. 12, pp. 37-54; GONZÁLEZ SÁNCHEZ, Carlos Alberto. Dineros de ventura: la varia fortuna de la emigración a Indias (siglos XVI-XVII). Sevilla: Secretariado de Publicaciones de la Universidad de Sevilla, 1995; ARAMBURU ZUDAIRE, José Miguel. Vida y fortuna
} 
encontramos ante un interés por acercarse a la cara más desconocida del desplazamiento de españoles a América -la emigración ilegal- aportando datos que permiten conocer con más detalle este tipo de trasvase de población y saber la suerte de muchos ellos; gracias al uso de distintas fuentes podemos adentrarnos en la vida de los peninsulares una vez establecidos en el continente.

En síntesis, durante estos años se observa el resurgir de la cuantificación del fenómeno migratorio, dando lugar a la aparición de nuevas cifras apoyadas en variedad de fuentes documentales. Del mismo modo, se avanza en el conocimiento cualitativo gracias a las investigaciones que centran la atención en aspectos distintos como fue el caso del arte, la cultura, las familias, etc. También se comienza a vislumbrar un relativo aumento de trabajos que atiende a la participación del sexo femenino. Volveremos a ello.

Con la entrada del siglo XX y, tras haber quedado atrás las celebraciones del V Centenario del Descubrimiento de América, decayó el número de publicaciones. Siguieron realizándose, no obstante, algunas investigaciones y apareciendo ediciones importantes. En primer lugar, predominaron trabajos de carácter regional. Valgan como ilustración los de Manuel Hernández González $(2002,2005)$ y Félix Rodríguez Mendoza (2004) sobre la emigración canaria durante el periodo colonial; el editado por José Manuel Azcona Pastor (2015) en relación con la migración vasca y navarra, y el de Antonio García-Abásolo acerca de los andaluces en Cuba durante los siglos $\mathrm{XVI}$ al XVIII ${ }^{27}$. En otras ocasiones, estas investigaciones se centraron en el estudio de los españoles que se encontraban ya en el continente americano, más que en el fenómeno migratorio en sí; por ejemplo el texto de María del Mar Barrientos sobre los gaditanos de las Antillas a través de los expedientes de bienes de difuntos (Cádiz, 2000) ${ }^{28}$. También fueron interesantes las comparativas sobre distintas zonas, pongamos por caso la elaborada por Carlos Sixirei Paredes referente a la emigración andaluza y gallega $(2006)^{29}$.

En estos primeros años del nuevo siglo volvieron a editarse obras de carácter general debidas a conocidos especialistas en el tema: Rosario Márquez, José

del emigrante navarro a Indias (siglos XVI-XVII). Pamplona: Gobierno de Navarra, Departamento de Educación, Cultura y Deportes, D.L., 1999.

${ }^{27}$ HERNÁNDEZ GONZALEZ, Manuel. La otra emigración canaria a América: mulatos y negros libres y esclavos (1670-1820). Revista de Historia Canaria. 2002, n. 184, pp. 181-198; HERNÁNDEZ GONZÁLEZ, Manuel. La emigración canaria a América. La Laguna: Centro de la Cultura Popular Canaria, 2005; RODRÍGUEZ MENDOZA, Félix. La emigración del noroeste de Tenerife a América durante 1750-1830 [tesis doctoral]. Universidad de La Laguna, 2004; AZCONA PASTOR, José Manuel (ed.). Identidad y estructura de la emigración vasca y navarra hacia Iberoamérica siglos (XVI-XXI): Redes sociales y desarrollo socioeconómico. Thomson Reuters Aranzadi, 2015; GARCÍA-ABÁSOLO, Antonio. Andaluces de Cuba (siglos XVI a XVIII). En: NAVARRO GARCÍA, Jesús Raúl (coord.). Cuba y Andalucía entre las dos orillas. Sevilla: Consejo Superior de Investigaciones Científicas 2002, pp. 55-151.

${ }^{28}$ BARRIENTOS MÁRQUEZ, María del Mar. Gaditanos en las Antillas: un acercamiento a su realidad socioeconómica a través de los expedientes de Bienes de Difuntos durante el Siglo XVII. Cádiz: Servicio de Publicaciones de la Universidad de Cádiz, 2000.

${ }_{29}$ SIXIREI PAREDES, Carlos. Andalucía y Galicia. Dos modelos de emigración regional a América. En: AA. VV. Encuentro de Latinoamericanistas Españoles: Viejas y nuevas alianzas entre América Latina y España. España: CEEIB, 2006, pp.184-194. 
Manuel Azcona, Nicolás Sánchez-Albornoz y Germán Rueda, entre otros. Este último, en colaboración con Consuelo Soldevilla, realizó un importante trabajo de síntesis, similar al elaborado por Carlos Martínez Shaw en 1994, reuniendo toda la información existente sobre los emigrantes, y aportando un amplio listado final de bibliografía a modo de estado de la cuestión ${ }^{30}$. Fueron aportes realizados a partir de la reunión de datos obtenidos previamente, que, aunque no añaden conclusiones novedosas, sí permitien visualizar la evolución del fenómeno en periodos de tiempo amplios.

En esta misma línea de análisis globales debemos mencionar la reciente publicación La Grande migration. De l'Espagne à l'Amérique (1492-1700), elaborada por Alain Hugon, en la que el autor explora una documentación diferente generada por la migración oficial durante varios siglos como fueron, por ejemplo, los escritos reales, los periódicos guardados por expatriados, la correspondencia familiar o los textos judiciales, y se acerca a numerosas cuestiones que añaden otras visiones al movimiento migratorio.

Nuevos volúmenes colectivos analizaron el fenómeno migratorio, no sólo americano. El primero de ellos, coordinado por Alicia Alted y Almudena Asenjo, fue publicado en 2006, bajo el título genérico De la España que emigra a la España que acoge: en él se encuentran varios artículos específicos sobre la emigración hacia las Indias. El segundo, titulado Historia Comparada de las migraciones en las Américas, fue editado en 2014 y, aunque no atiende únicamente al movimiento de españoles, sí contiene algunas contribuciones en esta línea; en concreto la de Patricia Escandón constituye una sinopsis de los conocimientos sobre la población española que cruzó el Océano durante los siglos XVI y XVII ${ }^{31}$. Estos libros atesoran el atractivo de ofrecer una visión interdisciplinar del fenómeno, al ser observado desde distintas disciplinas.

Como podemos observar, en estas primeras décadas del siglo XX hallamos una gran variedad y diversificación de los temas tratados, dejándose casi de lado la cuantificación del fenómeno migratorio para centrarse en nuevos asuntos. Por poner algunos ejemplos, se realizaron estudios sobre las bibliotecas y libros que pasaban

\footnotetext{
${ }^{30}$ MÁRQUEZ MACÍAS, Rosario. Embarcar para las Indias: la emigración en la etapa colonial (14931824). Andalucía en la historia. 2014, n. 46, pp. 8-11; AZCONA PASTOR, José Manuel. Los fundamentos de la emigración española hacia América (siglos XVI-XXI). En: AZCONA PASTOR, José Manuel; MARTíN DE LA GUARDIA, Ricardo y PÉREZ SÁNCHEZ, Guillermo Ángel (eds.). España en la era global (1492-1898). Madrid: Sílex Universidad, 2017, pp. 361-404; SÁNCHEZ-ALBORNOZ, Nicolás. La emigración española a América en medio milenio: pautas sociales. Historia social. 2002, n. 42, pp. 41-58; SÁNCHEZ-ALBORNOZ, Nicolás y LLORDÉN MIÑAMBRES, Moisés. Migraciones iberoamericanas: reflexiones sobre economía, política y sociedad. Colombres, Asturias: Fundación Archivo de Indianos, 2003; RUEDA HERNANZ, Germán y SOLDEVILLA ORIA, Consuelo. Españoles emigrantes en América (siglos XVI-XX). Madrid: Arco, 2000.

${ }^{31}$ ALTEDVIGIL, Alicia y ASENJO, Almudena (coord.). De la España que emigra a la España que acoge. Madrid: Fundación Francisco Largo Caballero, 2006; GALEANA, Patricia (coord.). Historia comparada de las migraciones en las Américas. México: Universidad Nacional Autónoma de México; Instituto Panamericano de Geografía e Historia, 2014; ESCANDÓN, Patricia. "Esta tierra es la mejor que calienta el sol”. La emigración española a América, siglos XVI-XVII. En: GALEANA, Patricia (coord.). Historia comparada de las migraciones en las Américas. México: Universidad Nacional Autónoma de México; Instituto Panamericano de Geografía e Historia, 2014, pp. 19-31.
} 
al continente, como son los de Rosario Márquez Macías (2002, 2016), León Carlos Álvarez Santaló (2003), Pedro José Rueda Ramírez (2001, 2055), y Carlos Alberto González-Sánchez $(2000,2006,2014)$; en relación con el mundo privado de los pobladores de la América española, como el Antonio García-Abásolo (2006); y sobre la utilización de identidades fingidas en Indias para evitar ser encontrados, debidos a Rocío Sánchez Rubio e Isabel Testón Núñez $(2008,2010)^{32}$.

Al margen de estas novedades, se van a continuar algunas líneas de investigación ya tratadas, como la fortuna o desventura de los emigrantes, la legislación migratoria, o los trámites para obtener los pasajes y el viaje en $\mathrm{si}^{33}$.

Si nos detenemos a valorar los avances logrados hasta la actualidad, podemos señalar que han sido muy numerosos; a día de hoy poseemos un conocimiento bastante amplio del trasvase de población española al continente americano durante el periodo colonial. Sin embargo, debemos señalar que aún nos encontramos con algunas deficiencias, especialmente en lo que al siglo XVII se refiere, pues los datos conocidos son solo regionales o basados en conjeturas, careciendo de un trabajo general acerca de la emigración en dichos años. De ahí, la importancia de continuar

${ }^{32}$ MÁRQUEZ MACÍAS, Rosario. El trasvase cultural a América. Las bibliotecas privadas de los emigrantes españoles en el siglo XVIII. Sevilla: Aconcagua Libros, 2002; MÁRQUEZ MACÍAS, Rosario. Comercio de libros con América en el Siglo XVIII. CLIO América. 2016, vol. 4, n. 7, pp. 151182; ÁLVAREZ SANTALÓ, León Carlos. El filtro ideológico: libros y pasajeros. En: BOUTET, Guiomar de Carlos (coord.). España y América: un océano de negocios: quinto centenario de la Casa de la Contratación 1503-2003. Madrid: Sociedad Estatal Quinto Centenario, 2003, pp. 161-174; RUEDA RAMÍREZ, Pedro José. El control inquisitorial del libro enviado a América en la Sevilla del siglo XVII. En: PEÑA DÍAZ, Manuel; RUIZ PÉREZ, Pedro y SOLANA PUJALTE, Julián (coords.). La cultura del libro en la Edad Moderna: Andalucía y América. Universidad de Córdoba, Servicio de Publicaciones, 2001, pp. 255-270; RUEDA RAMÍREZ, Pedro José. Negocio e intercambio cultural: el comercio de libros con América en la carrera de Indias (siglo XVII). Sevilla: Secretariado de Publicaciones de la Universidad de Sevilla, 2005; GONZÁLEZ-SÁNCHEZ, Carlos Alberto. Emigrantes y comercio de libros en el virreinato del Perú. Biblios: Revista electrónica de bibliotecología, archivología y museología. 2000, n. 6; GONZÁLEZ-SÁNCHEZ, Carlos Alberto. Libros europeos en las Indias del siglo XVIII: una aproximación desde el tráfico transatlántico. La formación de la cultura virreinal. 2006, vol. 3, pp. 337-366; GONZÁLEZ-SÁNCHEZ, Carlos Alberto. Misión náutica. De libros, discursos y prácticas culturales en la Carrera de Indias de los siglos XVI y XVII. Cuadernos de Historia Moderna. 2014, Anejos, n. 13, pp. 71-86; GONZÁLEZ-SÁNCHEZ, Carlos Alberto. El comercio de libros entre Europa y América en la Sevilla del siglo XVI. Impresores, libreros y mercaderes. Colonial Latin American Review. 2014, vol. 23, n. 3, pp. 439-465; GARCÍA-ABÁSOLO, Antonio. El mundo privado de los pobladores de la América española. Ámbitos. Revista de estudios de ciencias sociales y humanidades. 2006, n. 16, 2006, pp. 17-30; SÁNCHEZ RUBIO, Rocío y TESTÓN NÚÑEZ, Isabel. "Fingiendo llamarse... para no ser conocido": cambios nominales y emigración a Indias, siglos XVIXVIII. Norba. Revista de Historia. 2008, n. 21, pp. 213-239; TESTÓN NÚÑEZ, Isabel y SÁNCHEZ RUBIO, Rocío. Identidad fingida y migraciones atlánticas (siglos XVI-XVIII). En: SALINERO, Gregorio y TESTÓN NÚÑEZ, Isabel (eds.). Un juego de engaños: movilidad, nombres y apellidos en los siglos XV a XVIII. Madrid: Casa Velázquez, 2010, pp. 87-102.

${ }^{33}$ BARRIENTOS MÁRQUEZ, María del Mar. Fortuna y Muerte. Andaluces en América en la primera mitad del siglo XVIII. Cádiz: Servicio de publicaciones de Universidad de Cádiz, 2003; MIRA CABALLOS, Esteban. Bancarrota y América: flujo y reflujo en una tierra de frontera. Badajoz: Junta de Extremadura-Consejería de Cultura, 2003; MARTíNEZ RODRíGUEZ, José Luis. Pasajeros a Indias. Viajes trasatlánticos en el siglo XVI. Madrid: Fondo de Cultura Económica de España, 2001; SAINZ VARELA, José Antonio. Los Pasajeros a Indias. Tábula: revista de archivos de Castilla y León. 2006, n. 9, pp. 11-72; RODRÍGUEZ LORENZO, Sergio Manuel. El contrato de pasaje en la Carrera de Indias (1561-1622). Historia Mexicana. 2017, vol. 66, n. 3, pp. 1479-1571. 
la investigación en tal período.

También podemos mencionar, como posible nueva línea de investigación, el análisis de las distintas fuentes localizadas en el continente americano, todavía escasamente tratadas por los especialistas en la materia. Estos documentos permitirían profundizar en la llegada de los peninsulares a América como en sus vidas una vez allí instalados, además de posibilitar la comparación de datos y cifras: los peninsulares y los obtenidos en las colonias. Se trata de una labor compleja: analizar el fenómeno migratorio desde ambos lados del Océano, dada la amplitud de la información y el elevado número de fuentes a examinar; buena muestra de ello es la reciente publicación de la historiadora Amelia Almorza, titulada "No se hace pueblo sin ellas". Mujeres españolas en el Virreinato de Perú: emigración y movilidad social (siglos $X V I-X V I I)^{34}$, en la que nos detendremos más adelante.

Otra labor que queda por emprender es la unificación dentro de una misma investigación de aspectos cualitativos y cuantitativos, ya que, por regla general, salvo algunas excepciones, los análisis siempre suelen ser acometidos con una de estas dos metodologías: su complementariedad supondrá la obtención de una información mucho más rica y completa.

Por último, al ritmo de los avances en la historiografía de género, se ha ido intercalando el estudio de las mujeres emigrantes. Siendo aún de escaso número, no es de extrañar que su atención se incremente con el tiempo. A este asunto dedicamos el siguiente epígrafe.

\title{
3. La emigración femenina a América durante la época colonial. Un análisis olvidado
}

\begin{abstract}
"Mucho se ha hablado y escrito sobre la participación del hombre, del caballo, incluso del perro en la conquista del Nuevo Mundo. Muy poco se ha escrito, no obstante, de la participación de la mujer, y de su importantísima labor en todos los aconteceres de lo que supuso el descubrimiento, conquista y colonización de las nuevas tierras descubiertas" ${ }^{\prime 3}$.
\end{abstract}

Nos parece interesante comenzar con esta afirmación realizada en 1995 por Juan Francisco Maura King, resaltando la importancia de la figura femenina en la evolución del Nuevo Mundo y dejando ver la necesidad de realizar estudios que ahondasen en dicha cuestión, pues como veremos, no fue hasta los inicios del siglo XXI cuando las mujeres adquirieron protagonismo en los trabajos sobre emigración, conquista y colonización española de América.

Sí bien es cierto que en el siglo XX las obras sobre esta materia fueron escasas, ya en la primera mitad de la centuria nos encontramos con algunos acercamientos al tema: uno de los primeros fue el realizado por Cesáreo Fernández sobre la mujer

\footnotetext{
${ }^{34}$ ALMORZA HIDALGO, Amelia. "No se hace pueblo sin ellas". Mujeres españolas en el Virreinato de Perú: emigración y movilidad social (siglos XVI - XVII). Madrid: CSIC; Universidad de Sevilla; Diputación de Sevilla, 2018.

${ }_{35}$ MAURA KING, Juan Francisco. Mujeres hispanas en la conquista del Nuevo Mundo: a la vanguardia de los acontecimientos. Revista de Estudios Hispánicos. 1995, n. 22, pp. 185-204.
} 
española en Indias (1902). Se trataba de una disertación en la que pretendía dejar constancia de la presencia de las mujeres peninsulares en América al considerar que su figura necesitaba ser rescatada ${ }^{36}$.

Estas aproximaciones iniciales van a centrarse en el análisis de la legislación, que regulaba tanto su desplazamiento como sus circunstancias, una vez instaladas al otro lado del Océano. En relación con dicho asunto, hay que destacar el texto de Richard Konetzke por ser uno de los pioneros en resaltar la presencia de mujeres en el fenómeno migratorio en sí. No era tan sólo una recopilación de las leyes que les afectaban: realizaba un análisis para demostrar la relevancia del número de quienes pasaron a Indias ${ }^{37}$.

Durante la segunda mitad del siglo XX, continuaron apareciendo distintos textos en la misma línea que el realizado por Cesáreo Fernández; los historiadores centraron su atención en el estudio de las que viajaron a América en los momentos iniciales de conquista y colonización, y con especial atención, en las esposas de los conquistadores o en quienes contaron con algún tipo de privilegio, por ser las únicas cuya huella se conservaba en las fuentes analizadas: crónicas y narraciones contemporáneas a la época. No obstante, estamos ante investigaciones que atendían a las mujeres ya instaladas en Indias más que al propio fenómeno migratorio. En este sentido, dos libros importantes fueron el de Nancy O'SullivanBeare (1956) y el de Carmen Pumar (1988). La primera de ellas abordó la presencia de las mujeres españolas en las distintas zonas de las colonias americanas y se detuvo en algunas que tuvieron un papel relevante a través de una lectura detenida de los textos de los cronistas, rescatando las escasas referencias que aportaban; y la segunda, se interesó, además, por los modos de vida y las aportaciones culturales, apoyándose en las mismas fuentes y en otros estudios realizados previamente ${ }^{38}$.

En las últimas décadas del siglo podemos apreciar que se le concedió cierta importancia a la presencia y desplazamiento de la mujer española a América; buena muestra de ello es la existencia de apartados específicos en ejemplares de carácter general sobre la Historia de América Latina. Valga como ejemplo el capítulo elaborado por Asunción Lavrin en uno de los volúmenes de la obra The Cambridge History of Latin America, titulado "Women in Spanish American colonial society"

\footnotetext{
${ }^{36}$ FERNÁNDEZ DURO, Cesáreo. La mujer española en Indias. Madrid, 1902.

${ }^{37}$ KONETZKE, Richard. La emigración de las mujeres españolas a América durante la época colonial. Revista Internacional de Sociología. 1945, año III, n. 9, pp. 123-150; Otros trabajos sobre la misma materia fueron: OTS CAPDEQUÍ, José María. Bosquejo histórico de los derechos de la mujer en la legislación de Indias. Madrid: Reus, 1920; OTS CAPDEQUÍ, José María. El sexo como circunstancia modificativa de la capacidad jurídica en nuestra legislación de Indias. AHDE. 1930, n. 7, pp. 311-380.

${ }^{38}$ O'SULLIVAN-BEARE, Nancy. Las mujeres de los conquistadores. Madrid: Compañía Bibliográfica Española, 1956; PUMAR MARTíNEZ, Carmen. Españolas en Indias: mujeres-soldados, adelantadas y gobernadoras. Madrid: Anaya, 1988. Otras publicaciones con la misma temática: ORTEGA MARTíNEZ, Ana María. Mujeres españolas en la conquista de México. México: Vargas Rea, 1945; ACOSTA DE SAMPER, Soledad. Las esposas de los conquistadores. Boletín de La Academia de la Historia del Valle de Cauca. 1957, vol. 25, n. 108, pp. 140-154; VILLAFAÑE, María José. La mujer española en la conquista y colonización de América. Cuadernos Hispanoamericanos. 1964, n. 175176, pp. 125-142; ESTEVA FABREGAT, Claudio. La mujer española en la conquista de América. Comentaris d'Antropologia Cultural. 1983, n. 5, pp. 33-57.
} 
(1984): en el aborda el primer movimiento de mujeres españolas hacia las tierras recién descubiertas, resaltando la importancia del matrimonio y de las relaciones familiares, tratando de forma resumida el establecimiento y la emigración femenina, así como sus ocupaciones y educación ${ }^{39}$.

El decenio final del siglo presenció la aparición de nuevas materias y una diversificación de las fuentes utilizadas. Por un lado, se realizaron investigaciones sobre la vida cotidiana de algunas españolas asentadas en el continente americano, entre las que nos encontramos con las de María del Carmen Pareja y la de Antonio García-Abásolo, por citar algunas, elaboradas a partir del examen de los expedientes de bienes de difuntos ${ }^{40}$. Mención especial merece el libro "Presencia de la mujer sevillana en Indias: vida cotidiana"; de la autora arriba citada; supone una buena ilustración de este tipo de análisis al aportar un conocimiento bastante completo sobre los modos de vida de estas mujeres, acercándose a diferentes aspectos tales como los preparativos del viaje, las vinculaciones familiares y sociales, su posición dentro de los hogares, sus contribuciones en el mundo de la cultura o su relación con la religiosidad, si bien hay que mencionar que solo se trata de una pequeña muestra de las mujeres, al centrarse solo en las naturales o vecinas de Sevilla; además sería interesante completar la información obtenida de los autos de bienes de difuntos con otro tipo de documentos ${ }^{41}$.

Por otra parte, las consecuencias del fenómeno migratorio en la España que dejaban atrás también despertó el interés de los historiadores. El tema de las esposas abandonadas fue tratado de forma magistral por María José de la Pascua (1994, 1998). Si bien no aborda la emigración como tal, la historia de las mujeres en relación con la emigración a América incluye un nuevo apartado, pues las mujeres participaban, indirectamente, del fenómeno migratorio de los hombres. En este sentido -junto a los trabajos citados de De La Pascua- destacan los iniciales de María Ángeles Gálvez (1997), Rocío Sánchez Rubio e Isabel Testón (1997). En ellos se descubren otras fuentes: las requisitorias generadas en España o en la correspondencia privada encontrada en los expedientes realizados por la Inquisición en territorio americano; volveremos a estos últimos más adelante ${ }^{42}$. Retomarán el

\footnotetext{
${ }^{39}$ LAVRIN, Asunción. Women in Spanish American colonial society. En: BETHELL, Leslie (ed.). The Cambridge History of Latin America. Vol. 2. Cambridge University Press, 1984, pp. 322-355.

${ }^{40}$ PAREJA ORTIZ, María del Carmen. Vida cotidiana de María de Morales: una portuense en México en el siglo XVI. Revista de historia de El Puerto. 1991, n. 6, pp. 33-52; PAREJA ORTIZ, María del Carmen. Aproximación a la mujer a través de los bienes de difuntos. Gades. 1992, n. 20, pp. 221-236; PAREJA ORTIZ, María del Carmen. Nueva visión de la mujer española en Indias aspectos profesionales. En: SARABIA VIEJO, María Justina (coord.). Europa e Iberoamérica, cinco siglos de intercambios: actas. Vol. I. Sevilla: Junta de Andalucía, Consejería de Cultura, 1992, pp. 405-422; PAREJA ORTIZ, María del Carmen. Aspectos de la vida cotidiana de mujeres de Huelva en las Indias: relación entre Lepe y América. Siglo XVI. En: TORRES RAMÍREZ, Bibiano (coord.). Huelva y América: actas de las XI Jornadas de Andalucía y América, Universidad de Santa María de la Rábida, marzo-1992. Vol. 1. Huelva: Diputación Provincial de Huelva, 1993, pp. 361-385; GARCíA-ABÁSOLO, Antonio. Mujeres andaluzas en la América colonial (1550-1650). Revista de Indias. Enero-abril 1989, vol. XLIX, n. 185, pp. 91-110.

41 PAREJA ORTIZ, María del Carmen. Presencia de la mujer sevillana en Indias: vida cotidiana. Sevilla: Diputación Provincial, 1994.

42 PASCUA SÁNCHEZ, María José de la. La cara oculta del sueño indiano: mujeres abandonadas en el Cádiz de la Carrera de Indias. Chronica nova: Revista de Historia Moderna de la Universidad de
} 
asunto de la legislación pero en este caso, y en conexión con lo anterior, atendiendo a las leyes relacionadas con la regulación de los matrimonios, la marcha de hombres casados, y la situación de las mujeres cuyos maridos deciden viajar ${ }^{43}$. Estos textos posibilitan conocer las circunstancias de las formas de vida de las mujeres, comúnmente desamparadas tras partir los hombres de la familia, mujeres solas ante las dificultades cotidianas de la supervivencia. Desde el punto de vista metodológico hay que destacar el interés de las fuentes documentales utilizadas, al aportar importante información sobre la vida privada de los individuos a los que hacían referencia.

Durante estos años la emigración femenina se convirtió en materia de investigación de Juan Francisco Maura King, quien desarrolló numerosos trabajos sobre esta cuestión; atendió sobre todo al siglo XVI, centrándose en mujeres singulares, como ya había ocurrido en épocas previas, incluyendo en ocasiones otros grupos: un ejemplo, las esclavas ${ }^{44}$.

Asimismo, esta modalidad de obra también fue reemprendida por autores como Amanda Ángel en su libro Spanish Women in the New World: The Transmission of a Model Polity to New Spain, 1521-1570 (1997), y Blanca López en La figura femenina en los narradores testigos de la Conquista $(1997)^{45}$.

La llegada del siglo XXI supuso un auge de este tipo de investigaciones, aunque en su mayoría continuaron haciendo referencia a los primeros momentos de conquista y colonización, prestando menos atención a los siglos XVII y XVIII; siguieron perpetuándose los contenidos ya mencionados; sin embargo el empuje de los asuntos relacionados con la Historia de las mujeres y la Historia de género, por lógica hubo de incidir en los temas migratorios: comenzaron a ver la luz algunos volúmenes colectivos específicos sobre estas cuestiones. En cuanto a la continuación de tendencias previas podemos diferenciar dos líneas. Por un lado, publicaciones referentes a las primeras mujeres establecidas en el continente americano; aunque fueron varias, valga como ilustración la de Juan Francisco Maura

Granada. 1993-1994, n. 21, pp. 441-468; PASCUA SÁNCHEZ, María José de la. Mujeres solas: historias de amor y de abandono en el mundo hispánico. Málaga: Servicio de Publicaciones, Centro de Ediciones de la Diputación de Málaga, 1998; GÁLVEZ RUÍZ, María Ángeles. Emigración a Indias y fracaso conyugal. Chronica nova: Revista de Historia Moderna de la Universidad de Granada. 1997, n. 24, pp. 79-102; SÁNCHEZ RUBIO, Rocío y TESTÓN NÚÑEZ, Isabel. Mujeres abandonadas. Mujeres olvidadas. Cuadernos de Historia Moderna. 1997, n. 19, pp. 91-120.

${ }^{43}$ MARTíNEZ MARTíNEZ, María del Carmen. "Vida maridable" algunas peculiaridades en la emigración a las indias. Anuario jurídico y económico escurialense. 1991, n. 23, pp. 349-364; MUÑOZ GARCÍA, María José. La condición jurídica de la mujer casada en Indias. Anuario de la Facultad de Derecho de la Universidad de Extremadura. 1991, n. 9, pp. 455-476.

${ }_{44}$ MAURA KING, Juan Francisco. En busca de la verdad: Algunas mujeres excepcionales de la Conquista. Hispania. 1993, vol. 76, n. 4, pp. 904-910; MAURA KING, Juan Francisco. Esclavas españolas en el Nuevo Mundo: una nota histórica. Colonial Latin American Historical Review. 1993, vol. 2, n. 2, pp. 185-194; MAURA KING, Juan Francisco. Mujeres hispanas... Op. cit.; MAURA KING, Juan Francisco. La épica olvidada de la conquista de México: María de Estrada, Beatriz Bermúdez de Velasco y otras mujeres de armas tomar. Hispanófila. 1996, n. 118, pp. 65-74.

${ }^{45}$ ÁNGEL, Amanda Patricia. Spanish Women in the New World: The Transmission of a Model Polity to New Spain, 1521-1570 [tesis doctoral]. University of California, 1997; LÓPEZ DE MARISCAL, Blanca. La figura femenina en los narradores testigos de la Conquista. México, D.F.: El Colegio de México, Programa Interdisciplinario de Estudios de la Mujer, 1997. 
titulada Españolas de Ultramar en la historia y en la literatura: aventureras, madres, soldados, virreinas, gobernadoras, adelantadas, prostitutas, empresarias, monjas, escritoras, criadas y esclavas en la expansión ibérica ultramarina (siglos XV a XVII). Se trata de un examen de los textos y documentos más significativos de la conquista para demostrar que las mujeres estuvieron presentes en todo momento, desempeñando un rol relevante infravalorado por la historiografía. Dada la naturaleza de los documentos, el protagonismo corresponde a las mujeres principales; no obstante encontramos también a algunas otras rescatadas por las fuentes notariales $(2005)^{46}$.

Por otra parte, se mantiene el interés por las mujeres abandonadas, cuestión que las autoras citadas desarrollarán en los años próximos a sus aportaciones iniciales. María Ángeles Gálvez (2000, 2004), María José de la Pascua (2005), Ana María Presta (2011), María Eugenia Monzón (2012), Amelia Almorza y Reyes Rojas (2015) contribuyeron con aportaciones muy interesantes. Sus análisis se basaron en las fuentes ya mencionadas para este tipo de estudios: requisitorias y expedientes de vida maridable o de la Inquisición. Incidiremos en ello en un epígrafe específico, dedicado a la correspondencia privada ${ }^{47}$.

\footnotetext{
${ }^{46}$ MAURA KING, Juan Francisco. Españolas de Ultramar en la historia y en la literatura: aventureras, madres, soldados, virreinas, gobernadoras, adelantadas, prostitutas, empresarias, monjas, escritoras, criadas y esclavas en la expansión ibérica ultramarina (siglos XV a XVII). Valencia: Universidad de Valencia, 2005. Otras obras en la misma línea fueron: GONZÁLEZ DEL CAMPO, María Isabel. Mujeres fuertes y emprendedoras. Cinco castellanas en Indias en el siglo XVI. En: MORALES PADRÓN, Francisco (coord.). XIII Coloquio de Historia Canario-Americana; VIII Congreso Internacional de Historia de América (AEA) (1998). Cabildo de Gran Canaria, 2000, pp. 1141-1151; MAURA KING, Juan Francisco. Adelantadas, virreinas y aventureras en los primeros años de la conquista de América. Lemir: Revista de Literatura Española Medieval y del Renacimiento. 2002, n. 6, pp. 1-11; MAURA KING, Juan Francisco. Mujeres españolas empresarias en las Américas. Cuadernos Hispanoamericanos. 2004, n. 643, pp. 76-85; ENCONTRA Y VILALTA, María José. Andaluzas en la capital de la Nueva España, en el siglo XVI. En: CABRERA ESPINOSA, Manuel y LÓPEZ CORDERO, Juan Antonio (dirs.). VI Congreso virtual sobre Historia de las Mujeres. Jaén: Archivo Histórico Diocesano de Jaén, 2014, pp. 135-160; MAURA KING, Juan Francisco. Señoras y esclavas blancas en las Américas: Isabel de Bobadilla y su esclava Isabel. Cuadernos Hispanoamericanos. 2014, n. 769-770, pp. 78-88; MAURA KING, Juan Francisco. Mujeres hispanolusas en la expansión ultramarina de los siglos XV y XVI. Cuadernos Hispanoamericanos. 2015, n. 781-782, pp. 4-23; LÓPEZ DE MARISCAL, Blanca. Había mucha falta de tales mujeres de Castilla. Cuadernos Hispanoamericanos. 2015, n. 781-782, pp. 24-37.

47 GÁLVEZ RUIZ, María Ángeles. Mujeres y "maridos ausentes" en Indias. En: MORALES PADRÓN, Francisco (coord.). XIII Coloquio de Historia Canario-Americana. Op. cit., pp. 1162-1173; GÁLVEZ RUIZ, María Ángeles. Las parejas imperfectas: Viajes a Ultramar y ausencias de la vida maridable. Siglo XVII. En: DÁVILA MENDOZA, Dora (coord.). Historia, Género y Familia en Iberoamérica, siglos XVI-XX. Caracas: Universidad Católica Andrés Bello, 2004, pp. 67-101; PASCUA SÁNCHEZ, María José de la. Las relaciones familiares: historias de amor y conflicto. En: MORANT DEUSA, Isabel (coord.). Historia de las mujeres en España y América Latina. Vol. 2. Madrid: Cátedra, 2005, pp. 287316; PRESTA, Ana María. Estados alterados. Matrimonio y vida maridable en charcas tempranocolonial. Población y sociedad. Ene./Jun. 2011, vol. 18, n. 1, pp. 17-105; MONZÓN PERDOMO, María Eugenia. Ni solteras, ni casadas, ni viudas... Las mujeres ante la emigración masculina a América (siglos XVIII-XIX). En: GRIMALDI PEÑA, Isabel (ed.). XX Coloquio de Historia Canario-Americana. Cabildo de Gran Canaria, 2014, pp. 1015-1025; ALMORZA HIDALGO, Amelia y ROJAS GARCÍA, Reyes. Los expedientes de vida maridable del Archivo General de Indias: análisis de un estudio de caso. En: VASSALLO, Jaqueline y GARCÍA, Noelia (coord.). América en la burocracia de la monarquía española. Documentos para su estudio. Córdoba (Argentina): Brujas, 2015, pp. 111-130.
} 
En cuanto a los trabajos específicos sobre emigración femenina nos encontramos dos modalidades. En primer lugar, algunas investigaciones de carácter regional, como la de Carmen Purroy, en torno a la mujer navarra (2000), o la de María José Lorenzo sobre las ayamontinas $(2000)^{48}$. En segundo lugar, análisis generales que tratan diversos aspectos: las características comunes de estas migraciones han sido objeto de autores como Anore Horton (2001),Victoria Eugenia Corbacho (2012) y Allyson Poska (2012) ${ }^{49}$; el trayecto hacia el Nuevo Mundo fue tocado por Blanca López (2002) ${ }^{50}$; y la cuantificación así como la importancia de las relaciones de parentesco fueron estudiadas por Amelia Almorza (2005, 2010, 2018); el último de sus trabajos, ya citado, supone un intento de complementar el fenómeno migratorio desde ambos lados del Océano; comienza la autora presentando un resumen de datos generales sobre emigración a América -partiendo de estudios anteriores- centrándose, con posterioridad, en aspectos concretos de las emigrantes, una vez instaladas en Lima, usando documentos localizados en el continente americano. Ello le permite conocer cuestiones como la movilidad y el ascenso de las mujeres en su ciudad de destino. Ese es su principal acierto ${ }^{51}$.

Tal y como ya hemos mencionado, este interés general por la Historia de las mujeres dio lugar a la edición de distintos, volúmenes colectivos. Entre ellos debemos destacar cuatro grandes obras:

Primera: Mujer y emigración, una perspectiva plural: actas del Coloquio Internacional, coordinada por Julio Hernández y Domingo González, recopilación de textos donde se aborda la emigración femenina desde distintas disciplinas y en diferentes épocas (2008). Si bien no está dedicado exclusivamente a América, encontramos algunas menciones interesantes; valga por caso, el artículo de Ofelia Rey ${ }^{52}$.

${ }^{48}$ PURROY Y TURRILLAS, Carmen. La mujer navarra. Un caso excepcional en la emigración a América. En: MORALES PADRÓN, Francisco (coord.). XIII Coloquio de Historia Canario-Americana. Op. cit., pp. 1174-1185; LORENZO DOMÍNGUEZ, María José. La mujer ayamontina y la emigración a Indias en época colonial: esperanzas e ilusiones, abandono y olvido. En: AA. VV. V Jornadas de Historia de Ayamonte. Ayamonte: Ayuntamiento de Ayamonte, Área de Cultura, 2000, pp. 98-110.

${ }^{49}$ HORTON, M. Anore. New Perspectives on Women and Migration in Colonial Latin America. Program in Latin American Studies, Princeton University, 2001; CORBACHO GONZÁLEZ, Victoria Eugenia. Un género olvidado para un tiempo silenciado: las mujeres de la emigración a América durante el siglo XVII. En: SERRANO MARTÍN, Eliseo (coord.). De la tierra al cielo: Líneas recientes de investigación en Historia Moderna. Vol. 2. Zaragoza: Fundación Española de Historia Moderna, Institución Fernando el Católico, 2012, pp. 887-902; POSKA, Allyson. Campesinas transatlánticas Las mujeres y la migración en el imperio español a finales del siglo XVIII. Nuevo Mundo. Mundos Nuevos. 2012, n. 12.

50 LÓPEZ DE MARISCAL, Blanca. El viaje a la Nueva España entre 1540 y 1625: el trayecto femenino. En: GARCÍA, Juan Andreo, y GUARDIA, Sara Beatriz (coord.). Historia de las mujeres en América Latina. Perú: Centro de estudios de la mujer en la historia de América Latina, 2002, pp. 89109.

${ }^{51}$ ALMORZA HIDALGO, Amelia. "Si son mujeres, ellas verán lo que les conviene". La Migración femenina hacia el Virreinato del Perú. 1570-1600. En: AA. VV. X Jornadas Interescuelas, Actas del Congreso. Argentina: Departamento de Historia de la Universidad Nacional de Rosario, 2005; ALMORZA HIDALGO, Amelia. Sibling relations in the Spanish emigration to America: $1560-1600$. European Review of History: Revue européenne d'histoire. Oct. 2010, vol. 17, n. 5, pp. 735-752; ALMORZA HIDALGO, Amelia. "No se hace pueblo sin ellas". Op. cit.

${ }^{52}$ HERNÁNDEZ BORGE, Julio y GONZÁLEZ LOPO, Domingo L. (coord.). Mujer y emigración una perspectiva plural: actas del Coloquio Internacional. Santiago de Compostela, 23-24 de noviembre de 
Segunda: El protagonismo de la mujer en las corrientes migratorias españolas, coordinado por Xosé Amancio Liñares Giraut: recoge una serie de estudios que analizan la emigración contemporánea española desde la perspectiva femenina (2009); a pesar de estar centrado en la época no colonial, hace algunas referencias a este periodo en determinados ensayos como los de Teresa González o Raúl Soutelo ${ }^{53}$.

Tercera: coordinada por Sara Beatriz Guardia y titulada Viajeras entre dos mundos: relata los viajes de mujeres llevados a cabo desde los siglos XVI al XX; contiene un capítulo concreto en el que aparecen trabajos sobre migración femenina a Indias $(2012)^{54}$.

Y cuarta: El género en movimiento: Familias y migraciones. Sus coordinadoras son María Eugenia Zavala de Cosío y Virginie Rozée Gómez; presenta un interesante panorama sobre el impacto de las migraciones en las relaciones de género así como en los vínculos familiares $(2014)^{55}$.

No podemos finalizar este apartado sin mencionar la celebración de la exposición No fueron solos. Mujeres en la conquista y la colonización de América, que tuvo lugar en el año 2012 en el Museo Naval de Madrid, pues es una muestra inequívoca de que en las últimas décadas estamos asistiendo a una concienciación cada vez mayor del papel relevante que tuvo la mujer en las relaciones con el Nuevo Mundo, y ello está dando lugar a la multiplicación de este tipo de trabajos. Obviamente aún queda mucho por hacer ${ }^{56}$.

2006. Universidad de Santiago de Compostela: Servicio de Publicaciones, 2008; REY CASTELAO, Ofelia. Las migraciones femeninas de Antiguo Régimen en su contexto europeo. En: HERNÁNDEZ BORGE, Julio y GONZÁLEZ LOPO, Domingo L. (coords.). Mujer y emigración una perspectiva plural: actas del Coloquio Internacional, Santiago de Compostela, 23-24 de noviembre de 2006. Universidad de Santiago de Compostela, Servicio de Publicaciones, 2008, pp. 39-68.

${ }^{53}$ LIÑARES GIRAUT, Xosé Amancio (coord.). El protagonismo de la mujer en las corrientes migratorias españolas. Vigo: Grupo España Exterior, 2009; GONZÁLEZ PÉREZ, Teresa. Las mujeres canarias en el sueño americano. En: LIÑARES GIRAUT, Xosé Amancio (coord.). El protagonismo de la mujer... Op. cit., pp. 163-188; SOUTELO VÁZQUEZ, Raúl. El protagonismo de las mujeres en las redes migratorias familiares: una visión a través de las fuentes epistolares. En: LIÑARES GIRAUT, Xosé Amancio (coord.). El protagonismo de la mujer en las corrientes migratorias españolas. Vigo: Grupo España Exterior, 2009, pp. 207-230.

${ }_{54}$ GUARDIA, Sara Beatriz (coord.). Viajeras entre dos mundos. Dourados: Universidade Federal da Grande Dourados, 2012; MARTíNEZ MARTíNEZ, María del Carmen. Inquietudes, viajes y equipajes. (S. XVI). En: GUARDIA, Sara Beatriz (coord.). Viajeras entre dos mundos. Op. cit., pp. 55-79; NARBONA CARRIÓN, María Dolores. Anne Bradstreet (1612-1672): La cara femenina de los primeros viajes al Continente Americano. (S. XVII). En: GUARDIA, Sara Beatriz (coord.). Viajeras entre dos mundos. Op. cit., pp. 81-103; LOACH, Bárbara. Viajera en el camino de la tenacidad. En: GUARDIA, Sara Beatriz (coord.). Viajeras entre dos mundos. Op. cit., pp. 105-124; MARTíNEZ I ÀLVAREZ, Patricia. Mujeres que viajaron de España a la América colonial y del cuerpo propio al texto escrito. Lima, XVII. En: GUARDIA, Sara Beatriz (coord.). Viajeras entre dos mundos. Op. cit., pp. 125147.

${ }^{55}$ ZAVALA DE COSíO, María Eugenia y ROZÉE GÓMEZ, Virginie (coords.). El género en movimiento: Familias y migraciones. México D.F.: Colegio de México, 2014.

${ }^{56}$ Esta exposición dio lugar a la publicación de un libro: SÁNCHEZ FONNSECA, Ana (coord.). No fueron solos. Mujeres en la conquista y colonización de América. Ministerio de Defensa, 2012. 
En resumen, tras el examen de las publicaciones mencionadas a lo largo de este epígrafe podemos observar que a pesar de los avances alcanzados aún seguimos hallando importantes vacios, no existiendo ninguna obra que permita conocer en profundidad cómo fue la emigración de la mujer a Indias durante todo el periodo colonial. Consideramos de vital importancia el desarrollo de análisis que aporten datos importantes en este sentido y que demuestren la importancia que el sexo femenino tuvo en el fenómeno migratorio. No dejamos de reconocer, sin embargo, lo complejo de esta labor al tener que aunar fuentes de diversa naturaleza para alcanzar un conocimiento detallado sobre su participación, pues las referencias a ellas son inferiores a las relativas a los hombres. Rescatar su presencia en los documentos puede resultar una tarea nada fácil.

\section{Letras cruzando el Océano. La emigración a América en época colonial a través de la correspondencia privada}

En la actualidad, el análisis de la correspondencia privada se encuentra a la vanguardia de los estudios históricos, al haberse reconocido su importante valía como documento de primer orden que permite adentrarse en el mundo de las mentalidades, las emociones, las creencias o los modos de vida, entre otros muchos temas; buena muestra de ello es la reciente publicación de dos importantes volúmenes: Escribir cartas, una historia milenaria, de Armando Petrucci, y Un mundo de escrituras. Aportes a la historia de la cultura escrita, elaborado por Martyn Lyons y Rita Marquilhas ${ }^{57}$. Esta fuente es utilizada para acercarse a numerosos acontecimientos; en este caso nos centraremos en las investigaciones que conectan, de un lado, las migraciones hacia el continente americano durante los siglos de dominio español y, de otro, las cartas particulares.

Sí bien es cierto que el uso de los epistolarios como objeto de análisis tuvo sus orígenes en la segunda mitad del siglo XX, no fue hasta el siglo actual cuando comenzó a alcanzar mayor auge. De cualquier modo, es preciso resaltar que el pionero en este tipo de trabajos fue Enrique Otte, quien, ya a partir del año 1964 comenzó su interés por la transcripción de las cartas utilizándolas como base de sus estudios, realizando diversos artículos, y libros como Letters and People of the Spanish Indies: Sixteenth Century, editado junto a James Lockhart (1976). En 1988 publicó su gran volumen Cartas privadas de emigrantes a Indias, 1540-1616, en el que recuperaba un importante corpus epistolar, procedente de las licencias de embarque a Indias, que abarcaba casi todo el siglo XVI y los primeros años del XVII, sentando así las bases para las futuras investigaciones ${ }^{58}$.

\footnotetext{
${ }^{57}$ PETRUCCI, Armando. Escribir cartas, una historia milenaria. Buenos Aires: Ediciones Ampersand, 2018; LYONS, Martyn y MARQUILHAS, Rita. Un mundo de escrituras. Aportes a la historia de la cultura escrita. Buenos Aires: Ediciones Ampersand, 2018.

${ }^{58}$ OTTE, Enrique. Nueve cartas de Diego de Ordás. Historia Mexicana. 1964, vol. 14, n. 1, pp. 102130; OTTE, Enrique. Cartas privadas de Puebla del siglo XVI. Jahrbuch für Geschichte Lateinamerikas = Anuario de Historia de América Latina (JbLA). 1966, n. 3, pp. 10-87; OTTE, Enrique. Die europäischen Siedler und die Probleme der Neuen Welt. Jahrbuch für Geschichte Lateinamerikas = Anuario de Historia de América Latina (JbLA). 1969, n. 6, pp. 1-40; LOCKHART, James y OTTE, Enrique (eds.). Letters and People of the Spanish Indies: Sixteenth Century. Cambridge: Cambridge University Press, 1976; OTTE, Enrique. Cartas privadas de emigrantes a Indias, 1540-1616. Sevilla: V Centenario, D.L., 1988.
} 
Rescatado Enrique Otte como autor relevante, abandonamos ahora el orden cronológico para estructurar el epígrafe en función del tipo de análisis, para dar una mayor coherencia expositiva. En este sentido, a grandes rasgos, vamos a distinguir dos clases de textos: por un lado, aquellos que transcriben las cartas, añadiendo uno o varios capítulos; por otro, quienes se centran en analizar aspectos temáticos de la correspondencia privada apoyándose en misivas inéditas o ya editadas.

El primer grupo está encabezado por el ya mencionado texto de Enrique Otte, al que siguieron un importante número de trabajos, diferenciados por la naturaleza de los epistolarios: Isabelo Macías, Francisco Morales, Rosario Márquez y Werner Stangl fundamentaron sus volúmenes en las licencias de embarque custodiadas en el $\mathrm{AGI}^{59}$. Jesús María Usunáriz, Rocío Sánchez, Isabel Testón y María del Carmen Martínez recopilaron sus misivas de distintos fondos judiciales custodiados en archivos españoles y americanos, e insertas en diferentes procesos; en concreto, las dos primeras examinaron los repositorios del Tribunal del Santo Oficio en el Archivo General de la Nación de México, la tercera de ellas, lo hizo en el Archivo de la Real Chancillería de Valladolid, y Jesús María Usunáriz en diversos fondos de varios archivos guipuzcoanos y navarros ${ }^{60}$. Algunos fondos personales recabados de archivos privados de carácter familiar permitieron a Alfonso Arbelo desarrollar su ejemplar ${ }^{61}$. Estos libros han conseguido dar a conocer un importante número de cartas enviadas por particulares de uno al otro lado del Océano durante el periodo colonial, y demostrar la utilidad de estas series documentales para conocer diferentes aspectos del fenómeno migratorio. Del mismo modo, han servido de base para muchos textos que abordan dicha materia, en los que nos detendremos a continuación.

Han sido numerosos los ejemplares interesados en analizar la correspondencia privada como fuente de estudio para el desplazamiento de población española a Indias, aportando noticias sobre sus características, su utilidad, o sus posibilidades de investigación, permitiendo sumergirnos en dicho fenómeno de forma general. En esta línea han participado prácticamente todos los especialistas en la materia ${ }^{62}$.

\footnotetext{
${ }^{59}$ MACÍAS DOMÍNGUEZ, Isabelo y MORALES PADRÓN, Francisco. Cartas desde América, 17001800. Sevilla: V Centenario, 1991; MÁRQUEZ MACÍAS, Rosario. Historias de América. La emigración española en tinta y papel. Huelva: Ertoil Lubricantes, D.L., 1994; STANGL, Werner: Zwischen Authentizität und Fiktion. Die Korrespondenz spanischer Emigranten aus Amerika, 1492-1824. Colonia / Weimar / Viena, Böhlau, 2012.

${ }^{60}$ USUNÁRIZ GARAYOA, Jesús María. Una visión de la América del siglo XVIII: correspondencia de emigrantes guipuzcoanos y navarros. Madrid: MAPFRE, 1992; SÁNCHEZ RUBIO, Rocío y TESTÓN NÚNNEZ, Isabel. El hilo que une. Las relaciones epistolares entre el Viejo y el Nuevo Mundo (siglos XVI-XVIII). Cáceres: Editora Regional, 1999; SÁNCHEZ RUBIO, Rocío y TESTÓN NÚÑEZ, Isabel. Lazos de tinta, lazos de sangre. Cartas privadas entre el Nuevo y el Viejo Mundo (siglos XVI-XVIII). Universidad de Extremadura, 2014; MARTíNEZ MARTÍNEZ, María del Carmen. Desde la otra orilla: cartas de Indias en el Archivo de la Real Chancillería de Valladolid (siglos XVI-XVIII). León: Universidad de León, 2007.

${ }^{61}$ ARBELO GARCÍA, Adolfo. Al recibo de esta... Relaciones epistolares canario-americanas del siglo XVIII. Madrid: Idea, 2010.

${ }^{62}$ MÁRQUEZ MACÍAS, Rosario. La emigración a Indias a través de la correspondencia privada de los emigrantes, 1765- 1824. Rábida. 1988, n. 4, pp. 45-54; MÁRQUEZ MACÍAS, Rosario. Cuando América era un sueño. La correspondencia privada de los emigrantes vascos. En: AZCONA PASTOR, José Manuel (ed.). Sociedad "El Sitio" Ciclos de conferencias año 2003. Navarra: Sociedad "El Sitio", 2003, pp. 347-355; MÁRQUEZ MACÍAS, Rosario. Andalucía y América en las cartas de los
} 
Otro asunto reflejado en las cartas, ya tratado, es el abandono de las mujeres como consecuencia de la emigración masculina, abandono que las sumía en una situación muy complicada acorde con las carencias sociales y las marginaciones de género, en una sociedad desigual y patriarcal; las cartas permiten conocer su realidad, casi siempre difícil. Jesús María Usunáriz, María José de la Pascua, Isabel Testón y Rocío Sánchez han abordado dicha cuestión ${ }^{63}$.

En conexión con lo anterior, el amor y las emociones son materias de gran atractivo posibilitadas por las misivas, cuestiones que han captado la atención de varios autores como consecuencia de la expansión de la corriente historiográfica de la Historia de las emociones ${ }^{64}$. Como lo son las redes familiares y los modos de vida,

emigrantes a Indias. En: ROMERO SÁNCHEZ, Sixto (coord.). Academia Iberoamericana de La Rábida. Discursos de Ingreso (Período 1995-2014). Sociedad Andaluza de Educación Matemática Thales Academia Iberoamericana de La Rábida, 2014, pp. 581-593; EARLE, Rebbeca (ed.). Epistolary selves: letters and letter-writers, 1600-1945. Aldershot: Ashgate, 1999; CASTILLO GÓMEZ, Antonio. Tras la huella escrita de la gente común. En: CASTILLO GOMEZ, Antonio (coord.). Cultura escrita y clases subalternas: una mirada española. loartzun: Sendoa, 2001, pp. 9-34; CASTILLO GÓMEZ, Antonio. "El mejor retrato de cada uno": la materialidad de la escritura epistolar en la sociedad hispana de los siglos XVI y XVII. Hispania: Revista Española de Historia. 2005, vol. 65, n. 221, pp. 847-876; SIERRA BLAS, Verónica. "Puentes de papel": apuntes sobre las escrituras de la emigración. Horizontes Antropológicos. 2004, vol. 10, n. 22, pp. 121-147; TESTÓN NÚÑEZ, Isabel y SÁNCHEZ RUBIO, Rocío. "De todo he estado ignorante por no haber visto letra de vuestra merced". La correspondencia epistolar como vehículo de comunicación en la sociedad moderna. En: CASTELLANO, Juan Luis y LÓPEZ-GUADALUPE MUÑOZ, Miguel Luis (coords.). Homenaje a Antonio Domínguez Ortiz. Vol. 2. Universidad de Granada; Junta de Andalucía, Consejería de Innovación, Ciencia y Empresa, 2008, pp. 771-778; STANGL, Werner. Consideraciones metodológicas acerca de las cartas privadas de emigrantes españoles desde América, 1492-1824. El caso de las "cartas de llamada". Jahrbuch für Geschichte Lateinamerikas = Anuario de Historia de América Latina (JbLA). 2010, n. 47, pp. 11-35; STANGL, Werner. Un cuarto de siglo con Cartas privadas de emigrantes a Indias. Prácticas y perspectivas de ediciones de cartas transatlánticas en el Imperio español. Anuario de Estudios Americanos. 2013, vol. 70, n. 2, pp. 703-736; SÁNCHEZ RUBIO, Rocío y TESTÓN NÚÑEZ, Isabel. "Por mares de olvidos". Correspondencia privada e Inquisición en Nueva España. Siglos XVI-XVIII. En: VIEIRA, Alberto [et al.] (coords.). Escritas das movilidades. Funchal (Madeira): Secretaria Regional de Educação e Cultura; Centro de Estudos de História do Atlântico, 2011, pp. 46-80.

${ }^{63}$ SÁNCHEZ RUBIO, Rocío y TESTÓN NÚÑEZ, Isabel. Mujeres abandonadas. Op. cit.; USUNÁRIZ GARAYOA, Jesús María. Cartas de amor y cartas de emigrantes como prueba judicial en España (siglos XVI-XVIII). Hispanic Research Journal: Iberian and Latin American Studies. 2015, vol. 16, n. 4, pp. 296-310; SÁNCHEZ RUBIO, Rocío y TESTÓN NÚÑEZ, Isabel. "Nere Andrea, beti memorien daukedana". Amores y desamores de ultramar en el siglo XVIII. En: LARRAZA MICHELTORENA, María del Mar (coord.). Navarra y el Nuevo Mundo. Pamplona: Mintzoa, D.L., 2016, pp. 77-96; PASCUA SÁNCHEZ, María José de la. "A la sombra" de hombres ausentes: mujeres malcasadas en el mundo hispánico del setecientos. Studia Historica. Historia Moderna. 2016, vol. 38, n. 2, pp. 237285.

${ }^{64}$ MÁRQUEZ MACÍAS, Rosario. Cartas de amor y silencios: la correspondencia privada entre Buenos Aires y España en el siglo XVIII. Fundación. 2004-2005, n. 7, pp. 229-242; EARLE, Rebecca. Briefe und die Liebe im kolonialen Spanisch-Amerika (16. bis 18. Jahrhundert). En: HÄMMERLE, Christa y SAURER, Edith (eds.). Briefkulturen und ihr Geschlecht. Zur Geschichte der privaten Korrespondenzvom 16. Jahrhundert bis heute. Colonia/Weimar/Viena, Böhlau, 2003, pp. 135-162; EARLE, Rebecca. Letters and love in Colonial Spanish America. The Americas: A quarterly review of inter-american cultural history. 2005, vol. 62, n. 1, pp. 17-46; NAVARRO BONILLA, Diego. Sentir por escrito hacia 1650: cartas, billetes y lugares de memoria. En: TAUSIET CARLÉS, María y AMELANG, James S. (coords.). Accidentes del alma: las emociones en la Edad Moderna. Madrid: Abada, 2009, pp. 229-254; USUNÁRIZ GARAYOA, Jesús María. Palabras de amor en el mundo hispánico: emociones y sentimientos en la correspondencia privada del Siglo de Oro. En: MARTíNEZ 
y diferentes aspectos de la situación de las mujeres en la América colonial. Destacan los artículos de María del Carmen Pareja, Pilar Gonzalbo, Rocío Sánchez, Isabel Testón, Jesús María Usunáriz, y el libro de Alfonso Arbelo ${ }^{65}$. El género femenino captó la atención de Pilar García, Enrique Otte, Rosario Márquez y María Dolores Pérez ${ }^{66}$. Estas líneas temáticas presenten el atractivo de permitir en la vida privada de las familias y las parejas durante el periodo moderno. Las características especiales de los documentos examinados revelan las pequeñas historias de la cotidianeidad.

El Nuevo Mundo y las mujeres: una conexión que no sólo ha atraído a los historiadores. Los estudios filológicos también se han visto inmersos en esta materia, interesados en los aspectos lingüísticos de esta tipología documental, aportando textos como los de Eva Bravo, Pilar García, Marta Fernández y Mariano Franco ${ }^{67}$. Nos encontramos ante un buen ejemplo de la importancia de tratar un mismo asunto desde distintas disciplinas; estos trabajos aportan una interesante información sobre las formas de escritura, los niveles culturales o la lengua hablada

PASAMAR, Concepción y TABERNERO SALA, Cristina (coord.). Por seso e por maestría: homenaje a la profesora Carmen Saralegui. Universidad de Navarra, Ediciones Universidad de Navarra, 2012, pp. 555-576; PASCUA SÁNCHEZ, María José de la. La escritura privada y la representación de las emociones. En: BOLUFER PERUGA, Mónica; BLUTRACH JELÍN, Carolina y GOMIS COLOMA, Juan (coord.). Educar los sentimientos y las costumbres: una mirada desde la historia. Zaragoza: Institución Fernando el Católico (CSIC), 2014, pp. 81-108.

${ }^{65}$ PAREJA ORTIZ, María del Carmen. Las cartas de familia y la vida cotidiana de la mujer en Indias. En: AA. VV. Andalucía y América. Actas del II Congreso de Historia de Andalucía, Córdoba 1991. Córdoba: Consejería de Cultura y Medio Ambiente, 1994, pp. 105-116; GONZALBO AIZPURU, Pilar. La intimidad divulgada. La comunicación escrita en la vida privada en la Nueva España. Estudios de Historia Novohispana. 2002, n. 27, pp. 17-58; TESTÓN NÚNEEZ, Isabel y SÁNCHEZ RUBIO, Rocío. A casa hecha y a mesa puesta: la función del parentesco, la amistad y el paisanaje en la emigración española al Nuevo Mundo. Siglo XVI. Rábida. 2002, n. 21, pp. 17-34; TESTÓN NÚÑEZ, Isabel y SÁNCHEZ RUBIO, Rocío. "Para hacer la raya enviamos un sobrino": el papel de la familia y el parentesco en las relaciones de la América española (siglo XVI)". En: SALINERO, Gregorio (coord.). Mezclado y sospechoso: movilidad e identidades, España y América (siglos XVI-XVIII): coloquio internacional (29-31 de mayo de 2000). Madrid: Casa Velázquez, 2005, pp. 91-120; USUNÁRIZ GARAYOA, Jesús María. "Agur. Acaso, hasta el cielo": cartas de emigrantes vasco-navarros en Indias y sus lazos con el hogar (siglo XVIII). En: ARELLANO AYUSO, Ignacio (coord.). Modelos de vida y cultura en la Navarra de la modernidad temprana. Madrid: Instituto de Estudios Auriseculares (IDEA), 2016, pp. 365-383; ARBELO GARCÍA, Adolfo. Correspondencia canario-americana: familia y redes sociales (siglos XVIII y XIX). Madrid: Idea, 2011.

${ }^{66}$ GARCÍA MOUTON, Pilar. Las Mujeres que escribieron cartas desde América (siglos XVI-XVII). Anuario de lingüística hispánica. 1996-97, vol. 12-13, n. 1, pp. 319-326; OTTE, Enrique. La mujer de Indias en el siglo XVI. En: MORALES PADRÓN, Francisco (coord.). XIII Coloquio de Historia CanarioAmericana. Op. cit., pp. 1493-1505; MÁRQUEZ MACÍAS, Rosario. Cartas de mujeres emigrantes: nostalgias y recuerdos (siglos XVIII-XIX)". En: CHIVITE DE LEÓN, María José; HERNÁNDEZ PÉREZ, María Beatriz y MONZÓN PERDOMO, María Eugenia (coords.). Frontera y género: en los límites de la multidisciplinariedad. Plaza y Valdés, 2011, pp. 171-185; PÉREZ MURILLO, María Dolores. El rol de lo femenino en las cartas de emigrantes de la época colonial. Dos puntas, 2015, n. 11, pp. 79-102.

${ }^{67}$ BRAVO-GARCÍA, Eva. Tratamientos y cortesía en la correspondencia familiar indiana del siglo XVIII. Archivo de filología aragonesa. 2002-2004, vol. 59-60, n. 1, pp. 249-264; GARCÍA MOUTON, Pilar. Humor en las cartas privadas de emigrantes a Indias (1540-1616). Cuadernos del CEMYR. 2004, n. 12, pp. 139-154; FERNÁNDEZ ALCAIDE, Marta. Cartas de particulares en Indias del siglo XVI. Edición y estudio discursivo. Madrid: Iberoamericana; Frankfurt am Main: Vervuert, 2009; FRANCO FIGUEROA, Mariano. Cartas de mujeres en documentos americanos coloniales. Boletín de filología. 2011, vol. 46, n. 2, pp. 59-84. 
por aquellos españoles que viajaron a Indias y que van a transmitir a las sociedades allí establecidas.

Aparte de las líneas ya mencionadas, la diversidad de la información procedente de esta fuente documental queda patente en estudios como los de Isabelo Macías sobre fe y religiosidad, Lara Arroyo en torno a las relaciones comerciales, María del Carmen Martínez acerca de la minería de plata, Rosario Márquez sobre las formas de vestir de la época, y el de esta última -en coautoría con María Luisa Candaurelativo a la esclavitud femenina ${ }^{68}$.

No olvidemos tomos sobre epistolarios, que no siendo específicos sobre cartas de emigrantes a América, se detienen en este tipo de misivas; entre ellos se encuentran los realizados por Diego Navarro, Antonio Castillo, o José María Imízcoz y Lara Arroyo, por poner algún ejemplo ${ }^{69}$. En ellos queda reflejada la relevancia y el atractivo de la correspondencia privada para realizar análisis de una gran diversidad de aspectos, siendo utilizada por especialistas de distintas materias, no únicamente historiadores, muestra inequívoca de su valía como fuente documental.

Para finalizar, hemos de reseñar la aparición de volúmenes colectivos sobre correspondencia como consecuencia de la relevancia alcanzada por este tipo de estudios, que cuentan con trabajos sobre emigración de autores de referencia. Hemos de destacar dos de ellos: Cinco siglos de cartas. Historia y prácticas epistolares en las épocas moderna y contemporánea, y Cartas-Lettres-Lettere: discursos, prácticas y representaciones epistolares (siglos $X I V-X X$ ), ambos dirigidos por Antonio Castillo y Verónica Sierra. En el primero encontramos las interesantes contribuciones de María del Carmen Martínez en relación a las cartas privadas de emigrantes en los pleitos civiles, y Rosario Márquez sobre el amor y el olvido, manifiesto en el lenguaje epistolar; en el segundo, hallamos las aportaciones de Isabel Testón y Rocío Sánchez sobre familias extremeñas emigrantes, y Laura Martínez acerca de las redes de solidaridad ${ }^{70}$.

\footnotetext{
${ }^{68}$ MACÍAS DOMÍNGUEZ, Isabelo. Fe y religiosidad en las cartas de los emigrantes españoles a Indias (siglo XVIII). En: SARABIA VIEJO, María Justina (coord.). Europa e Iberoamérica. Op. cit., pp. 87-114; ARROYO RUIZ, Lara. Redes de influencia: relaciones privilegiadas en el comercio colonial a finales del siglo XVIII: los Marticorena y su correspondencia epistolar. Nuevo mundo, Mundos Nuevos. 2007, n. 7; MARTÍNEZ MARTÍNEZ, María del Carmen. Plata y minería en la correspondencia privada de Indias. En: PANIAGUA PÉREZ, Jesús y SALAZAR SIMARRO, Nuria (coords.). Ophir en las Indias: estudios sobre la plata americana: siglos XVI-XIX. Universidad de León, Servicio de Publicaciones, 2010, pp. 25-42; MÁRQUEZ MACÍAS, Rosario. La visualización del honor. Vestir conforme al estado. En: CANDAU CHACÓN, María Luisa (ed.). Las mujeres y el honor en la Europa Moderna. Huelva: Universidad de Huelva, Servicio de Publicaciones, 2014, pp. 319-333; MÁRQUEZ MACÍAS, Rosario y CANDAU CHACÓN, María Luisa. Las otras mujeres de América: las esclavas negras en tiempos de la Colonia. Un estudio a través de la correspondencia privada. Visitas al Patio. 2016, n. 10, pp. 75-92.

${ }^{69}$ NAVARRO BONILLA, Diego. Del corazón a la pluma archivos y papeles privados femeninos en la Edad Moderna. Salamanca: Ediciones Universidad de Salamanca, 2004; CASTILLO GÓMEZ, Antonio. Entre la pluma y la pared: una historia social de la escritura en los Siglos de Oro. Madrid: Akal, 2006; CASTILLO GÓMEZ, Antonio. «Me alegraré que al recibo de ésta...». Cuatrocientos años de prácticas epistolares (siglos XVI a XIX). Manuscrits: Revista d'història moderna. 2011, n. 29, pp. 19-50; IMÍZCOZ BEUNZA, José María y ARROYO RUIZ, Lara. Redes sociales y correspondencia epistolar del análisis cualitativo de las relaciones personales a la reconstrucción de redes egocentradas. Redes: Revista hispana para el análisis de redes sociales. 2011, n. 21, pp. 98-138.

${ }^{70}$ CASTILLO GÓMEZ, Antonio y SIERRA BLAS, Verónica (dirs.). Cinco siglos de cartas. Historia y
} 
En definitiva, el uso de la correspondencia privada ha dado a conocer multitud de aspectos que hasta el momento no habían tenido protagonismo, permitiéndonos acceder a gran cantidad de detalles sobre estos desplazamientos y de la vida privada en general. Sin duda, se trata de una línea de investigación hoy en auge, que seguirá siendo fructífera en el futuro, pues, aunque ya son muchos los estudios realizados, aún quedan algunas lagunas, especialmente en lo que al siglo XVII se refiere, considerando la escasez de las que han salido a la luz en relación con este periodo. De igual modo, también sería interesante examinar los numerosos fondos regionales y provinciales -como ya hicieron José Miguel Aramburu y Jesús María Usunáriz para el caso vasco y navarro- con la finalidad de localizar nuevas misivas, así como en diferentes archivos americanos en los que se podrían hallar cartas escritas desde la Península y enviadas a América.

\section{Recapitulación. Migraciones, mujeres y epístolas}

En la actualidad son numerosas las investigaciones existentes sobre emigración española a América durante la época colonial. Sin embargo, aún se pueden apreciar ciertos desniveles y diferencias en cuanto a los tres siglos: en tanto los siglos XVI y XVIII han sido más trabajados y contamos con la existencia de cifras globales, del siglo XVII solo poseemos datos casi siempre regionales, siendo sus estudios más escasos; por ello, consideramos importante la elaboración de textos que den a conocer de forma completa la evolución del fenómeno durante dicho periodo.

Al observar las obras se puede apreciar una evolución en las metodologías empleadas: los primeros textos presentaban análisis cuantitativos, posteriormente pasaron a predominar las observaciones cualitativas que desembocaron en el estudio de gran cantidad de líneas temáticas. Además, se ha producido una regionalización de los trabajos, por lo que consideramos necesario el intento de aglutinar todos los resultados existentes.

Del mismo modo, se aprecian cambios en las fuentes consultadas, añadiendo a las tradicionales licencias de embarque conservadas en el AGI, la correspondencia privada, los autos de bienes de difuntos, así como fuentes demográficas americanas, y otras procedentes de archivos locales españoles -procesos judiciales, protocolos notariales o registros parroquiales-. Esto ha permitido conocer con mayor

prácticas epistolares en las épocas moderna y contemporánea. Huelva: Universidad de Huelva, 2014; MÁRQUEZ MACÍAS, Rosario. El amor y el olvido en la correspondencia privada de los emigrantes en América. En: CASTILLO GÓMEZ, Antonio y SIERRA BLAS, Verónica (dirs.). Cinco siglos de cartas. Op. cit., pp. 275-290; MARTÍNEZ MARTÍNEZ, María del Carmen. Cartas privadas de emigrantes en pleitos civiles. En: CASTILLO GÓMEZ, Antonio y SIERRA BLAS, Verónica (dirs.). Cinco siglos de cartas. Historia y prácticas epistolares en las épocas moderna y contemporánea. Huelva: Universidad de Huelva, 2014, pp. 187-202; CASTILLO GÓMEZ, Antonio y SIERRA BLAS, Verónica (dirs.). CartasLettres-Lettere: discursos, prácticas y representaciones epistolares (siglos XIV-XX). Universidad de Alcalá: Servicio de Publicaciones, 2014; TESTÓN NÚÑEZ, Isabel y SÁNCHEZ RUBIO, Rocío. "Quien quiere, tarde olvida": cartas privadas de familias extremeñas entre España y América, siglos XVIXVIII. En: CASTILLO GÓMEZ, Antonio y SIERRA BLAS, Verónica (dirs.). Cartas-Lettres-Lettere. Op. cit., pp. 419-443; MARTÍNEZ MARTÍN, Laura. Escribir en cadena: solidaridad y control en las cartas de los emigrantes En: CASTILLO GÓMEZ, Antonio y SIERRA BLAS, Verónica (dirs.). Cartas-LettresLettere: discursos, prácticas y representaciones epistolares (siglos XIV-XX). Universidad de Alcalá, Servicio de Publicaciones, 2014, pp. 445-463. 
profundidad el proceso emigratorio, al ser investigado desde distintas perspectivas. En este sentido, sería interesante trabajar con fuentes de ambos lados del Océano, permitiendo de esta forma realizar una comparativa entre las cifras obtenidas en cada una de ellas.

En cuanto a los asuntos tratados, las investigaciones iniciales centraron su atención en las causas de la emigración, así como en la política migratoria, dejando paso después a una serie de estudios sobre cuantificación del fenómeno migratorio. Con el tiempo, y debido a la multiplicación de documentos analizados, fueron apareciendo nuevos asuntos a tratar, tales como la vida privada, las bibliotecas y libros que pasaban a América, o la utilización de identidades fingidas, entre muchos otros.

Aunque los primeros trabajos sobre el desplazamiento de españoles al continente americano aparecieron a finales del siglo XIX, no fue hasta la segunda mitad del XX cuando comenzaron a alcanzar relevancia. Los estudios de Peter Boyd-Bowman y Magnus Mörner supusieron un antes y un después y tuvieron gran transcendencia en el discurrir de esta línea de investigación. No obstante, hubo que esperar hasta el último decenio del siglo para que se produjese un auge importante de la materia.

Por lógica, los sucesos políticos marcan tendencias: así los años previos y posteriores a la celebración V Centenario del Descubrimiento, incrementaron actos, celebraciones y edición de textos consecuentes; decayendo después, hasta ser bastante escasos a día de hoy, pese a haberse producido el 525 aniversario de la llegada de Colón. Del mismo modo, también el interés social por la vida de las mujeres ha incrementado -desde los cambios políticos experimentados en España, hace cuarenta años- un acercamiento superior a su historia; por derivación, también a su vinculación con el proceso migratorio, como actores o como sujetos pasivos del proceso. Por ello, los trabajos han ido aumentando en las últimas décadas. No obstante, son aún poco numerosos y continúan existiendo importantes lagunas que nos impiden conocer al completo la implicación de las mujeres en este fenómeno. A pesar de ello, también debemos resaltar que se han logrado importantes avances como consecuencia de la multiplicación de los documentos tratados y de la aparición de distintas corrientes historiográficas interesadas en abordar tales asuntos como es el caso de la Historia de las emociones, la Historia de la familia o la Historia de la vida cotidiana.

En el siglo XX las obras sobre esta materia fueron escasas, pero ya nos encontrábamos con algunos acercamientos. Estas aproximaciones iniciales se centraron en el estudio de la legislación migratoria que regulaba su paso o en las primeras mujeres que cruzaron el Océano. Fue en la década final cuando la diversificación de fuentes documentales dio lugar a la aparición de nuevas temáticas como la vida cotidiana o las esposas abandonas como consecuencia de la emigración masculina. La llegada del siglo XXI supuso el auge definitivo de este tipo de investigaciones, manteniéndose hasta nuestros días. 
Por último, en cuanto a los trabajos sobre migraciones apoyados en la correspondencia privada, hoy en expansión, han generado importantes especialistas, uniendo en la actualidad a paleógrafos, especialistas en la historia de la lectura y la escritura, modernistas y comtemporaneistas. Gracias a las recopilaciones de epístolas realizadas por autores como Enrique Otte, Rosario Márquez, Isabelo Macías, y muchos otros, ha sido rescatado un ingente volumen de cartas que permite conocer mejor aspectos inaccesibles a través de otro tipo de fuentes. Los temas más comunes son la privacidad, las redes de paisanaje y familiares, el comercio y los negocios, la historia de género, la lingüística, y las emociones. La vida, en realidad.

Como conclusión, y a modo de recapitulación, podemos reseñar que el conocimiento de esta materia ha avanzado de forma considerable debido, especialmente, a la evolución en las metodologías, a la diversificación de las temáticas analizadas, y al aumento del interés de distintas disciplinas en dichos asuntos. Sin embargo, aún debemos plantearnos algunos retos: la unificación de todos los datos regionales para lograr de esta forma un conocimiento más completo, el análisis en profundidad de las distintas fuentes documentales existentes en el continente americano, todavía poco explotadas; en definitiva, la elaboración de investigaciones, compaginando métodos cuantitativos y cualitativos, y un análisis más profundo del papel de las mujeres, a fin de cubrir las lagunas existentes en relación con el siglo XVII.

\section{Bibliografía}

ACOSTA DE SAMPER, Soledad. Las esposas de los conquistadores. Boletín de La Academia de la Historia del Valle de Cauca. 1957, vol. 25, n. 108, pp. 140-154.

ALMORZA HIDALGO, Amelia y ROJAS GARCÍA, Reyes. Los expedientes de vida maridable del Archivo General de Indias: análisis de un estudio de caso. En: VASSALLO, Jaqueline y GARCÍA, Noelia (coord.). América en la burocracia de la monarquía española. Documentos para su estudio. Córdoba (Argentina): Brujas, 2015, pp. 111-130.

ALMORZA HIDALGO, Amelia. "No se hace pueblo sin ellas". Mujeres españolas en el Virreinato de Perú: emigración y movilidad social (siglos XVI - XVII). Madrid: CSIC; Universidad de Sevilla; Diputación de Sevilla, 2018.

ALMORZA HIDALGO, Amelia. "Si son mujeres, ellas verán lo que les conviene". La Migración femenina hacia el Virreinato del Perú. 1570-1600. En: AA. VV. $X$ Jornadas Interescuelas, Actas del Congreso. Argentina: Departamento de Historia de la Universidad Nacional de Rosario, 2005.

ALMORZA HIDALGO, Amelia. Sibling relations in the Spanish emigration to America: 1560 - 1600. European Review of History: Revue européenne d'histoire. Oct. 2010, vol. 17, n. 5, pp. 735-752. 
ALTEDVIGIL, Alicia y ASENJO, Almudena (coord.). De la España que emigra a la España que acoge. Madrid: Fundación Francisco Largo Caballero, 2006.

ALTMAN, Ida. Emigrantes y sociedad: Extremadura y América en el siglo XVI. Madrid: Alianza Editorial, 1992.

ÁLVAREZ SANTALÓ, León Carlos. El filtro ideológico: libros y pasajeros. En: BOUTET, Guiomar de Carlos (coord.). España y América: un océano de negocios: quinto centenario de la Casa de la Contratación 1503-2003. Madrid: Sociedad Estatal Quinto Centenario, 2003, pp. 161-174.

ANDREO GARCÍA, Juan y PROVENCIO GARRIGÓS, Lucía. Pasajeros a América: aportación al estudio de la emigración del Reino de Murcia durante el S. XVI. Anales de Historia Contemporánea. 1991, n. 8, pp. 97-130.

ANES ÁLVAREZ, Rafael. La emigración de asturianos a América. Colombres: Fundación Archivo de Indianos, 1993.

ÁNGEL, Amanda Patricia. Spanish Women in the New World: The Transmission of a Model Polity to New Spain, 1521-1570 [tesis doctoral]. University of California, 1997.

ARAMBURU ZUDAIRE, José Miguel. Vida y fortuna del emigrante navarro a Indias (siglos XVI-XVII). Pamplona: Gobierno de Navarra, Departamento de Educación, Cultura y Deportes, D.L., 1999.

ARBELO GARCÍA, Adolfo. Al recibo de esta... Relaciones epistolares canarioamericanas del siglo XVIII. Madrid: Idea, 2010.

ARBELO GARCÍA, Adolfo. Correspondencia canario-americana: familia y redes sociales (siglos XVIII y XIX). Madrid: Idea, 2011.

ARROYO RUIZ, Lara. Redes de influencia: relaciones privilegiadas en el comercio colonial a finales del siglo XVIII: los Marticorena y su correspondencia epistolar. Nuevo mundo, Mundos Nuevos. 2007, n. 7.

AZCONA PASTOR, José Manuel (ed.). Identidad y estructura de la emigración vasca y navarra hacia Iberoamérica siglos (XVI-XXI): Redes sociales y desarrollo socioeconómico. Thomson Reuters Aranzadi, 2015.

AZCONA PASTOR, José Manuel. Los fundamentos de la emigración española hacia América (siglos XVI-XXI). En: AZCONA PASTOR, José Manuel; MARTíN DE LA GUARDIA, Ricardo y PÉREZ SÁNCHEZ, Guillermo Ángel (eds.). España en la era global (1492-1898). Madrid: Sílex Universidad, 2017, pp. 361-404.

BARRIENTOS MÁRQUEZ, María del Mar. Fortuna y Muerte. Andaluces en América en la primera mitad del siglo XVIII. Cádiz: Servicio de publicaciones de Universidad de Cádiz, 2003. 
BARRIENTOS MÁRQUEZ, María del Mar. Gaditanos en las Antillas: un acercamiento a su realidad socioeconómica a través de los expedientes de Bienes de Difuntos durante el Siglo XVII. Cádiz: Servicio de Publicaciones de la Universidad de Cádiz, 2000.

BERNAL RODRíGUEZ, Antonio-Miguel y CAGIAO VILA, María del Pilar. Incorporación al mercado laboral e inserción social. En: VIVES, Pedro A.; VEGA, Pepa y OYAMBURU, Jesús (coord.). Historia general de la emigración española a lberoamérica. Madrid: Historia 16, D.L. 1992, pp. 275-330.

BORGES MORÁN, Pedro. La emigración de eclesiásticos a América en el siglo XVI. Criterios para su estudio. En: SOLANO PÉREZ-LILA, Francisco de Paula y DEL PINO DÍAZ, Fermín (coord.). América y la España del siglo XVI. Madrid: Consejo Superior de Investigaciones Científicas, 1982, pp. 47-62.

BORREGÓN RIVES, Vicente. La emigración española a América. Vigo: Imprenta Faro de Vigo, 1952.

BOYD-BOWMAN, Peter. Índice geobiográfico de más de 56 mil pobladores de la América Hispánica. México D.F.: Fondo de Cultura Económica, 1985.

BOYD-BOWMAN, Peter. La emigración Peninsular a América: 1520 a 1539. Historia Mexicana. 1963, vol. 13, n. 2, pp. 165-192.

BOYD-BOWMAN, Peter. La procedencia de los españoles de América: 1540 - 1559. Historia Mexicana. 1967, vol. 17, n. 1, pp. 37-71.

BOYD-BOWMAN, Peter. Pattersn of Spanish immigration to the Indies until 1600. Hispanic American Historical Review. 1976, n. 56, pp. 580-604.

BRADING, David. Los españoles en México hacia 1792. Historia Mexicana. Jul./Sep. 1973, vol. XXIII, n. 1, pp. 126-144.

BRADING, David. Mineros y comerciantes en el México borbónico (1763-1810). Madrid: FCE, 1975.

BRAVO-GARCÍA, Eva. Tratamientos y cortesía en la correspondencia familiar indiana del siglo XVIII. Archivo de filología aragonesa. 2002-2004, vol. 59-60, n. 1, pp. 249-264.

CAMUS, Matilde (ed.). Santander y el Nuevo Mundo. Santander: Centro de Estudios Montañeses, 1979.

CASAÚS ARZÚ, Marta Elena y MARTÍNEZ, Jesús. Planteamiento general del contexto socioeconómico: España e Iberoamérica. En: VIVES, Pedro A.; VEGA, Pepa y OYAMBURU, Jesús (coord.). Historia general de la emigración española a Iberoamérica. Madrid: Historia 16, D.L. 1992, pp. 151-176. 
CASTILLO GÓMEZ, Antonio y SIERRA BLAS, Verónica (dirs.). Cartas-LettresLettere: discursos, prácticas y representaciones epistolares (siglos XIV-XX). Universidad de Alcalá: Servicio de Publicaciones, 2014.

CASTILLO GÓMEZ, Antonio y SIERRA BLAS, Verónica (dirs.). Cinco siglos de cartas. Historia y prácticas epistolares en las épocas moderna y contemporánea. Huelva: Universidad de Huelva, 2014.

CASTILLO GÓMEZ, Antonio. "EI mejor retrato de cada uno": la materialidad de la escritura epistolar en la sociedad hispana de los siglos XVI y XVII. Hispania: Revista Española de Historia. 2005, vol. 65, n. 221, pp. 847-876.

CASTILLO GÓMEZ, Antonio. "Me alegraré que al recibo de ésta...». Cuatrocientos años de prácticas epistolares (siglos XVI a XIX). Manuscrits: Revista d'història moderna. 2011, n. 29, pp. 19-50.

CASTILLO GÓMEZ, Antonio. Entre la pluma y la pared: una historia social de la escritura en los Siglos de Oro. Madrid: Akal, 2006.

CASTILLO GÓMEZ, Antonio. Tras la huella escrita de la gente común. En: CASTILLO GÓMEZ, Antonio (coord.). Cultura escrita y clases subalternas: una mirada española. loartzun: Sendoa, 2001, pp. 9-34.

CASTRO SEOANE, José. Aviamiento y catálogo de las misiones que en el siglo XVI pasaron de España a Indias y Filipinas según los libros de la contratación. Madrid: Raycar, S.A. Impresores, 1960.

Catálogo de Pasajeros a Indias durante los siglos XVI, XVII y XVIII. Sevilla: Imprenta editorial de la Gavidia, 1940-1980.

CORBACHO GONZÁLEZ, Victoria Eugenia. Un género olvidado para un tiempo silenciado: las mujeres de la emigración a América durante el siglo XVII. En: SERRANO MARTÍN, Eliseo (coord.). De la tierra al cielo: Líneas recientes de investigación en Historia Moderna. Vol. 2. Zaragoza: Fundación Española de Historia Moderna, Institución Fernando el Católico, 2012, pp. 887-902.

CUESTA GUTIÉRREZ, Luisa. La emigración gallega a América. Santiago: Nos Publicacions galegas e Imp., 1932.

DÍAZ-TRECHUELO, Lourdes (coord.). La emigración andaluza a América. Siglos XVII y XVIII. Sevilla: Consejería de Cultura y Medio Ambiente, D.L. 1991.

DÍAZ-TRECHUELO, Lourdes y GARCÍA-ABASOLO, Antonio. Córdoba en la emigración andaluza al Nuevo Mundo en la primera mitad del siglo XVII. En: AA. VV. Actas del Congreso Internacional de Historia de América (Córdoba). Vol. II. Córdoba: Consejería de Cultura de la Junta de Andalucía; Monte de Piedad; Caja de Ahorros de Córdoba, 1988, pp. 53-74. 
DÍAZ-TRECHUELO, Lourdes. Emigración cordobesa a las Indias: siglo XVI. En: AA. VV. Primeras Jornadas de Andalucía y América: La Rábida. Diputación Provincial de Huelva; Instituto de Estudios Onubenses. 1981, vol. 1, pp. 405-426.

DUEÑAS OLMO, Antonio y GARRIDO ARANDA, Antonio. La emigración cordobesa a Indias en la segunda mitad del siglo XVII. En: AA. VV. Actas del Congreso Internacional de Historia de América (Córdoba). Vol. II. Córdoba: Consejería de Cultura de la Junta de Andalucía; Monte de Piedad; Caja de Ahorros de Córdoba, pp. 75-92.

DUPLÁ ANSUÁTEGUI, Antonio. Presencia vasca en América: 1492- 1992: una mirada crítica. Donostia: Tercera Prensa, D.L. 1992.

DURÁN LÓPEZ, Gonzalo. Pasajes a Indias a principios del siglo XVIII: precios y condiciones. En: EIRAS ROEL, Antonio (coord.). La Emigración española a Ultramar, 1492-1914. Ediciones Tabapress, 1991, pp. 199-214.

EARLE, Rebbeca (ed.). Epistolary selves: letters and letter-writers, 1600-1945. Aldershot: Ashgate, 1999.

EARLE, Rebecca. Briefe und die Liebe im kolonialen Spanisch-Amerika (16. bis 18. Jahrhundert). En: HÄMMERLE, Christa y SAURER, Edith (eds.). Briefkulturen und ihr Geschlecht. Zur Geschichte der privaten Korrespondenzvom 16. Jahrhundert bis heute. Colonia/Weimar/Viena, Böhlau, 2003, pp. 135-162.

EARLE, Rebecca. Letters and love in Colonial Spanish America. The Americas: $A$ quarterly review of inter-american cultural history. 2005, vol. 62, n. 1, pp. 17-46.

EIRAS ROEL, Antonio (coord.). La Emigración española a Ultramar, 1492-1914. Ediciones Tabapress, 1991.

EIRAS ROEL, Antonio y REY CASTELAO, Ofelia. Los gallegos y América. Madrid: Fundación MAPFRE, 1992.

EIRAS ROEL, Antonio. Sobre las motivaciones de la emigración gallega a América y otros aspectos. Un enfoque comparativo. Revista da Comisión Galega do Quinto Centenario. 1989, n. 2, pp. 57-72.

ENCONTRA Y VILALTA, María José. Andaluzas en la capital de la Nueva España, en el siglo XVI. En: CABRERA ESPINOSA, Manuel y LÓPEZ CORDERO, Juan Antonio (dirs.). VI Congreso virtual sobre Historia de las Mujeres. Jaén: Archivo Histórico Diocesano de Jaén, 2014, pp. 135-160.

ESCANDÓN, Patricia. "Esta tierra es la mejor que calienta el sol". La emigración española a América, siglos XVI-XVII. En: GALEANA, Patricia (coord.). Historia comparada de las migraciones en las Américas. México: Universidad Nacional Autónoma de México; Instituto Panamericano de Geografía e Historia, 2014, pp. 19-31. 
ESTEVA FABREGAT, Claudio. La mujer española en la conquista de América. Comentaris d'Antropologia Cultural. 1983, n. 5, pp. 33-57.

Estudios Migratorios Latinoamericanos. Buenos Aires: Centro de Estudios Migratorios Latinoamericanos, 1985-actualmente.

FERNÁNDEZ ALCAIDE, Marta. Cartas de particulares en Indias del siglo XVI. Edición y estudio discursivo. Madrid: Iberoamericana; Frankfurt am Main: Vervuert, 2009.

FERNÁNDEZ DURO, Cesáreo. La mujer española en Indias. Madrid, 1902.

FRANCO FIGUEROA, Mariano. Cartas de mujeres en documentos americanos coloniales. Boletín de filología. 2011, vol. 46, n. 2, pp. 59-84.

FRIEDE, Juan. Algunas observaciones sobre la realidad de la emigración española a América en la primera mitad del siglo XVI. Revista de Indias. 1952, n. 49, pp. 472-473.

FRIEDE, Juan. Los estamentos sociales en España y su contribución a la emigración en América. Revista de Indias. 1966, n. 103-104, pp. 13-30.

FRIEDE, Juan. The "Catalogo de Pasajeros» and Spanish Emigration to America to 1550. The Hispanic American Historical Review. 1951, n. 31, pp. 331-348.

GALEANA, Patricia (coord.). Historia comparada de las migraciones en las Américas. México: Universidad Nacional Autónoma de México; Instituto Panamericano de Geografía e Historia, 2014.

GÁLVEZ RUíZ, María Ángeles. Emigración a Indias y fracaso conyugal. Chronica nova: Revista de Historia Moderna de la Universidad de Granada. 1997, n. 24, pp. 79-102.

GÁLVEZ RUIZ, María Ángeles. Las parejas imperfectas: Viajes a Ultramar y ausencias de la vida maridable. Siglo XVII. En: DÁVILA MENDOZA, Dora (coord.). Historia, Género y Familia en Iberoamérica, siglos XVI-XX. Caracas: Universidad Católica Andrés Bello, 2004, pp. 67-101.

GÁLVEZ RUIZ, María Ángeles. Mujeres y "maridos ausentes" en Indias. En: MORALES PADRÓN, Francisco (coord.). XIII Coloquio de Historia CanarioAmericana; VIII Congreso Internacional de Historia de América (AEA) (1998). Cabildo de Gran Canaria, 2000, pp. 1162-1173.

GARCÍA MOUTON, Pilar. Humor en las cartas privadas de emigrantes a Indias (1540-1616). Cuadernos del CEMYR. 2004, n. 12, pp. 139-154. 
GARCÍA MOUTON, Pilar. Las Mujeres que escribieron cartas desde América (siglos XVI-XVII). Anuario de lingüística hispánica. 1996-97, vol. 12-13, n. 1, pp. 319326.

GARCÍA-ABÁSOLO, Antonio. Andaluces de Cuba (siglos XVI a XVIII). En: NAVARRO GARCÍA, Jesús Raúl (coord.). Cuba y Andalucía entre las dos orillas. Sevilla: Consejo Superior de Investigaciones Científicas 2002, pp. 55-151.

GARCÍA-ABÁSOLO, Antonio. El mundo privado de los pobladores de la América española. Ámbitos. Revista de estudios de ciencias sociales y humanidades. 2006, n. 16, 2006, pp. 17-30.

GARCÍA-ABÁSOLO, Antonio. Mujeres andaluzas en la América colonial (15501650). Revista de Indias. Enero-abril 1989, vol. XLIX, n. 185, pp. 91-110.

GIL-BERMEJO GARCÍA, Juana y PÉREZ-MALLAÍNA BUENO, Pablo Emilio. Los andaluces en la navegación transatlántica: la vida y la muerte en la Carrera de Indias a comienzos del siglo XVIII. En: TORRES RAMÍREZ, Bibiano y HÉRNADEZ PALOMO, José Jesús (coords.). Andalucía y América en el siglo XVIII: actas de las IV Jornadas de Andalucía y América. Vol. I. Consejo Superior de Investigaciones Científicas, 1985, pp. 271-296.

GÓNGORA, Mario. Los grupos de conquistadores en Tierra Firme (1509-1530). Fisonomía histórico-social de un tipo de conquista. Santiago de Chile: Centro de Historia Social, Universidad de Chile, 1962.

GONZALBO AIZPURU, Pilar. La intimidad divulgada. La comunicación escrita en la vida privada en la Nueva España. Estudios de Historia Novohispana. 2002, n. 27 , pp. 17-58.

GONZÁLEZ DEL CAMPO, María Isabel. Mujeres fuertes y emprendedoras. Cinco castellanas en Indias en el siglo XVI. En: MORALES PADRÓN, Francisco (coord.). XIII Coloquio de Historia Canario-Americana; VIII Congreso Internacional de Historia de América (AEA) (1998). Cabildo de Gran Canaria, 2000, pp. 1141-1151.

GONZÁLEZ LOPO, Domingo. Una aproximación a la emigración de Galicia occidental entre mediados del siglo XVII y el primer tercio del XX a través de las fuentes de protocolos y archivos parroquiales. Revista da Comisión Galega do Quinto Centenario. 1990, n. 6, pp. 135-169.

GONZÁLEZ PÉREZ, Teresa. Las mujeres canarias en el sueño americano. En: LIÑARES GIRAUT, Xosé Amancio (coord.). El protagonismo de la mujer en las corrientes migratorias españolas. Vigo: Grupo España Exterior, 2009, pp. 163188. 
GONZÁLEZ SÁNCHEZ, Carlos Alberto. Dineros de ventura: la varia fortuna de la emigración a Indias (siglos XVI-XVII). Sevilla: Secretariado de Publicaciones de la Universidad de Sevilla, 1995.

GONZÁLEZ-SÁNCHEZ, Carlos Alberto. El comercio de libros entre Europa y América en la Sevilla del siglo XVI. Impresores, libreros y mercaderes. Colonial Latin American Review. 2014, vol. 23, n. 3, pp. 439-465.

GONZÁLEZ-SÁNCHEZ, Carlos Alberto. Emigrantes y comercio de libros en el virreinato del Perú. Biblios: Revista electrónica de bibliotecología, archivología y museología. 2000, n. 6.

GONZÁLEZ-SÁNCHEZ, Carlos Alberto. Libros europeos en las Indias del siglo XVIII: una aproximación desde el tráfico transatlántico. La formación de la cultura virreinal. 2006, vol. 3, pp. 337-366.

GONZÁLEZ-SÁNCHEZ, Carlos Alberto. Misión náutica. De libros, discursos y prácticas culturales en la Carrera de Indias de los siglos XVI y XVII. Cuadernos de Historia Moderna. 2014, Anejos, n. 13, pp. 71-86.

GONZÁLVEZ PÉREZ, Vicente [et al.]. (coord.). Emigración española y portuguesa a América. Actas del II Congreso de la Asociación de Demografía Histórica. Alicante, abril de 1990, vol. 1. Universitat de València, Seminari d"Estudis sobre la Població del País Valencià; Diputación Provincial de Alicante, Instituto Alicantino de Cultura Juan Gil-Albert, 1991.

GUARDIA, Sara Beatriz (coord.). Viajeras entre dos mundos. Dourados: Universidade Federal da Grande Dourados, 2012.

HERNÁNDEZ BORGE, Julio y GONZÁLEZ LOPO, Domingo L. (coord.). Mujer y emigración una perspectiva plural: actas del Coloquio Internacional. Santiago de Compostela, 23-24 de noviembre de 2006. Universidad de Santiago de Compostela: Servicio de Publicaciones, 2008.

HERNÁNDEZ GONZÁLEZ, Manuel. Al margen de la Corona. La emigración del clero regular canario a América en la Edad Moderna. Tenerife: Ediciones Idea, 2018.

HERNÁNDEZ GONZÁLEZ, Manuel. La emigración canaria a América. La Laguna: Centro de la Cultura Popular Canaria, 2005.

HERNÁNDEZ GONZÁLEZ, Manuel. La otra emigración canaria a América: mulatos y negros libres y esclavos (1670-1820). Revista de Historia Canaria. 2002, n. 184, pp. 181-198.

HORTON, M. Anore. New Perspectives on Women and Migration in Colonial Latin America. Program in Latin American Studies, Princeton University, 2001. 
IMÍZCOZ BEUNZA, José María y ARROYO RUIZ, Lara. Redes sociales y correspondencia epistolar del análisis cualitativo de las relaciones personales a la reconstrucción de redes egocentradas. Redes: Revista hispana para el análisis de redes sociales. 2011, n. 21, pp. 98-138.

JACOBS, Auke Pieter. Los movimientos migratorios entre Castilla e Hispanoamérica durante el Reinado de Felipe III, 1598-1621. Amsterdam: Rodopi, 1995.

JACOBS, Auke Pieter. Pasajeros y polizones: algunas observaciones sobre la emigración española a las Indias durante el siglo XVI. Revista de Indias. 1983, vol. 43, n. 172, pp. 439-479.

KICZA, John. Empresarios coloniales: familias y negocios en la ciudad de México durante los Borbones. Madrid: FCE, 1983.

KONETZKE, Richard. La emigración de las mujeres españolas a América durante la época colonial. Revista Internacional de Sociología. 1945, año III, n. 9, pp. 123150.

LARA ZERÓN, María del Carmen. Inmigrantes clandestinos españoles y extranjeros en Nueva España a finales del siglo XVII. Temas americanistas. 1994, n. 11, pp. 25-39.

LATASSA LATASA, Pilar. Matrimonios clandestinos y matrimonios secretos (DCH). Max Planck Institute for European Legal History Research Paper Series. 2019, n. 11.

LAVRIN, Asunción. Women in Spanish American colonial society. En: BETHELL, Leslie (ed.). The Cambridge History of Latin America. Vol. 2. Cambridge University Press, 1984, pp. 322-355.

LEMUS LÓPEZ, Encarnación y MÁRQUEZ MACÍAS, Rosario. Los precedentes. En: VIVES, Pedro A.; VEGA, Pepa y OYAMBURU, Jesús (coords.). Historia general de la emigración española a Iberoamérica. Madrid: Historia 16, D.L. 1992, pp. 37-92.

LEMUS LÓPEZ, Encarnación. Ausente en Indias: una historia de la emigración extremeña a América. Madrid: Siruela, D.L., 1993.

LIÑARES GIRAUT, Xosé Amancio (coord.). El protagonismo de la mujer en las corrientes migratorias españolas. Vigo: Grupo España Exterior, 2009.

LOACH, Bárbara. Viajera en el camino de la tenacidad. En: GUARDIA, Sara Beatriz (coord.). Viajeras entre dos mundos. Dourados: Universidade Federal da Grande Dourados, 2012, pp. 105-124.

LOCKHART, James y OTTE, Enrique (eds.). Letters and People of the Spanish Indies: Sixteenth Century. Cambridge: Cambridge University Press, 1976. 
LOCKHART, James. Spanish Peru, 1532-1560: A Colonial Society. Madison: The University of Wisconsin Press, 1968.

LOHMANN VILLENA, Guillermo. Índice de los expedientes de bienes de difuntos en el Perú. Revista del Instituto peruano de investigaciones genealógicas. 1958, vol. XI, n. 11, pp. 58-133.

LÓPEZ DE MARISCAL, Blanca. El viaje a la Nueva España entre 1540 y 1625: el trayecto femenino. En: GARCÍA, Juan Andreo, y GUARDIA, Sara Beatriz (coord.). Historia de las mujeres en América Latina. Perú: Centro de estudios de la mujer en la historia de América Latina, 2002, pp. 89-109.

LÓPEZ DE MARISCAL, Blanca. Había mucha falta de tales mujeres de Castilla. Cuadernos Hispanoamericanos. 2015, n. 781-782, pp. 24-37.

LÓPEZ DE MARISCAL, Blanca. La figura femenina en los narradores testigos de la Conquista. México, D.F.: El Colegio de México, Programa Interdisciplinario de Estudios de la Mujer, 1997.

LORENZO DOMÍNGUEZ, María José. La mujer ayamontina y la emigración a Indias en época colonial: esperanzas e ilusiones, abandono y olvido. En: AA. VV. $V$ Jornadas de Historia de Ayamonte. Ayamonte: Ayuntamiento de Ayamonte, Área de Cultura, 2000, pp. 98-110.

LYONS, Martyn y MARQUILHAS, Rita. Un mundo de escrituras. Aportes a la historia de la cultura escrita. Buenos Aires: Ediciones Ampersand, 2018.

MACÍAS DOMÍNGUEZ, Isabelo y MORALES PADRÓN, Francisco. Cartas desde América, 1700-1800. Sevilla: V Centenario, 1991.

MACÍAS DOMÍNGUEZ, Isabelo. Fe y religiosidad en las cartas de los emigrantes españoles a Indias (siglo XVIII). En: SARABIA VIEJO, María Justina (coord.). Europa e Iberoamérica, cinco siglos de intercambios: actas. Vol. 2. Sevilla: Junta de Andalucía, Consejería de Cultura, 1992, pp. 87-114.

MACÍAS DOMÍNGUEZ, Isabelo. La emigración de Málaga y Jaén hacia América y Filipinas en el siglo XVII. En: TORRES RAMÍREZ, Bibiano y HÉRNADEZ PALOMO, José Jesús (coord.). Andalucía y América en el siglo XVIII: actas de las IV Jornadas de Andalucía y América. Vol. I. Consejo Superior de Investigaciones Científicas, 1985, pp. 1-28.

MACÍAS DOMÍNGUEZ, Isabelo. La llamada del Nuevo Mundo: la emigración española a América (1701-1750). Sevilla: Universidad de Sevilla, Secretariado de Publicaciones, 1999.

MACÍAS HERNÁNDEZ, Antonio. La emigración canaria, 1550-1980. Gijón: Júcar, 1992. 
MARCHENA FERNÁNDEZ, Juan. La emigración andaluza en el ejército de América. En: Primeras Jornadas de Andalucía y América: La Rábida. Diputación Provincial de Huelva, Instituto de Estudios Onubenses. 1981, vol. 1, pp. 461-462.

MÁRQUEZ MACÍAS, Rosario y CANDAU CHACÓN, María Luisa. Las otras mujeres de América: las esclavas negras en tiempos de la Colonia. Un estudio a través de la correspondencia privada. Visitas al Patio. 2016, n. 10, pp. 75-92.

MÁRQUEZ MACÍAS, Rosario. Andalucía y América en las cartas de los emigrantes a Indias. En: ROMERO SÁNCHEZ, Sixto (coord.). Academia Iberoamericana de La Rábida. Discursos de Ingreso (Período 1995-2014). Sociedad Andaluza de Educación Matemática Thales Academia Iberoamericana de La Rábida, 2014, pp. 581-593.

MÁRQUEZ MACÍAS, Rosario. Cartas de amor y silencios: la correspondencia privada entre Buenos Aires y España en el siglo XVIII. Fundación. 2004-2005, n. 7, pp. 229-242.

MÁRQUEZ MACÍAS, Rosario. Cartas de mujeres emigrantes: nostalgias y recuerdos (siglos XVIII-XIX)". En: CHIVITE DE LEÓN, María José; HERNÁNDEZ PÉREZ, María Beatriz y MONZÓN PERDOMO, María Eugenia (coords.). Frontera y género: en los límites de la multidisciplinariedad. Plaza y Valdés, 2011, pp. 171185.

MÁRQUEZ MACÍAS, Rosario. Comercio de libros con América en el Siglo XVIII. CLIO América. 2016, vol. 4, n. 7, pp. 151-182.

MÁRQUEZ MACÍAS, Rosario. Cuando América era un sueño. La correspondencia privada de los emigrantes vascos. En: AZCONA PASTOR, José Manuel (ed.). Sociedad "El Sitio" Ciclos de conferencias año 2003. Navarra: Sociedad "El Sitio", 2003, pp. 347-355.

MÁRQUEZ MACÍAS, Rosario. El amor y el olvido en la correspondencia privada de los emigrantes en América. En: CASTILLO GÓMEZ, Antonio y SIERRA BLAS, Verónica (dirs.). Cinco siglos de cartas. Historia y prácticas epistolares en las épocas moderna y contemporánea. Huelva. Universidad de Huelva, 2014, pp. 275-290.

MÁRQUEZ MACÍAS, Rosario. El trasvase cultural a América. Las bibliotecas privadas de los emigrantes españoles en el siglo XVIII. Sevilla: Aconcagua Libros, 2002.

MÁRQUEZ MACÍAS, Rosario. Embarcar para las Indias: la emigración en la etapa colonial (1493-1824). Andalucía en la historia. 2014, n. 46, pp. 8-11.

MÁRQUEZ MACÍAS, Rosario. Historias de América. La emigración española en tinta y papel. Huelva: Ertoil Lubricantes, D.L., 1994. 
MÁRQUEZ MACÍAS, Rosario. La emigración a Indias a través de la correspondencia privada de los emigrantes, 1765- 1824. Rábida. 1988, n. 4, pp. 45-54.

MÁRQUEZ MACÍAS, Rosario. La emigración española a América, 1765-1824. Oviedo: Universidad de Oviedo, 1995.

MÁRQUEZ MACÍAS, Rosario. La emigración gallega a América en la época del comercio libre (1765-1824). Revista da Comisión Galega do Quinto Centenario. 1989, n. 4, pp. 172-182.

MÁRQUEZ MACÍAS, Rosario. La visualización del honor. Vestir conforme al estado. En: CANDAU CHACÓN, María Luisa (ed.). Las mujeres y el honor en la Europa Moderna. Huelva: Universidad de Huelva, Servicio de Publicaciones, 2014, pp. 319-333.

MARTÍNEZ I ÀLVAREZ, Patricia. Mujeres que viajaron de España a la América colonial y del cuerpo propio al texto escrito. Lima, XVII. En: GUARDIA, Sara Beatriz (coord.). Viajeras entre dos mundos. Dourados: Universidade Federal da Grande Dourados, 2012, pp. 125-147.

MARTÍNEZ MARTÍN, Laura. Escribir en cadena: solidaridad y control en las cartas de los emigrantes En: CASTILLO GÓMEZ, Antonio y SIERRA BLAS, Verónica (dirs.). Cartas-Lettres-Lettere: discursos, prácticas y representaciones epistolares (siglos $X I V-X X$ ). Universidad de Alcalá, Servicio de Publicaciones, 2014, pp. 445-463.

MARTÍNEZ MARTÍNEZ, María del Carmen. "Vida maridable" algunas peculiaridades en la emigración a las indias. Anuario jurídico y económico escurialense. 1991, n. 23, pp. 349-364.

MARTÍNEZ MARTÍNEZ, María del Carmen. Cartas privadas de emigrantes en pleitos civiles. En: CASTILLO GÓMEZ, Antonio y SIERRA BLAS, Verónica (dirs.). Cinco siglos de cartas. Historia y prácticas epistolares en las épocas moderna y contemporánea. Huelva: Universidad de Huelva, 2014, pp. 187-202.

MARTÍNEZ MARTÍNEZ, María del Carmen. Desde la otra orilla: cartas de Indias en el Archivo de la Real Chancillería de Valladolid (siglos XVI-XVIII). León: Universidad de León, 2007.

MARTÍNEZ MARTÍNEZ, María del Carmen. Inquietudes, viajes y equipajes. (S. XVI). En: GUARDIA, Sara Beatriz (coord.). Viajeras entre dos mundos. Dourados: Universidade Federal da Grande Dourados, 2012, pp. 55-79.

MARTÍNEZ MARTÍNEZ, María del Carmen. La emigración castellano-leonesa al Nuevo Mundo (1517-1700). Junta de Castilla y León, Consejería de Cultura y Turismo, 1993. 
MARTÍNEZ MARTÍNEZ, María del Carmen. Plata y minería en la correspondencia privada de Indias. En: PANIAGUA PÉREZ, Jesús y SALAZAR SIMARRO, Nuria (coords.). Ophir en las Indias: estudios sobre la plata americana: siglos XVI-XIX. Universidad de León, Servicio de Publicaciones, 2010, pp. 25-42.

MARTÍNEZ RODRÍGUEZ, Enrique. La emigración a América desde la ciudad de Santiago en la época preestadística: problemas de fuentes y resultados. Revista da Comisión Galega do Quinto Centenario. 1990, n. 6, pp. 31-48.

MARTÍNEZ RODRÍGUEZ, José Luis. Pasajeros a Indias. Viajes trasatlánticos en el siglo XVI. Madrid: Fondo de Cultura Económica de España, 2001.

MARTÍNEZ SHAW, Carlos. La emigración española a América, 1492-1824. Colombres, Asturias: Archivo de Indianos, 1994.

MAURA KING, Juan Francisco. Adelantadas, virreinas y aventureras en los primeros años de la conquista de América. Lemir: Revista de Literatura Española Medieval y del Renacimiento. 2002, n. 6, pp. 1-11.

MAURA KING, Juan Francisco. En busca de la verdad: Algunas mujeres excepcionales de la Conquista. Hispania. 1993, vol. 76, n. 4, pp. 904-910.

MAURA KING, Juan Francisco. Esclavas españolas en el Nuevo Mundo: una nota histórica. Colonial Latin American Historical Review. 1993, vol. 2, n. 2, pp. 185194.

MAURA KING, Juan Francisco. Españolas de Ultramar en la historia y en la literatura: aventureras, madres, soldados, virreinas, gobernadoras, adelantadas, prostitutas, empresarias, monjas, escritoras, criadas y esclavas en la expansión ibérica ultramarina (siglos XV a XVII). Valencia: Universidad de Valencia, 2005.

MAURA KING, Juan Francisco. La épica olvidada de la conquista de México: María de Estrada, Beatriz Bermúdez de Velasco y otras mujeres de armas tomar. Hispanófila. 1996, n. 118, pp. 65-74.

MAURA KING, Juan Francisco. Mujeres españolas empresarias en las Américas. Cuadernos Hispanoamericanos. 2004, n. 643, pp. 76-85.

MAURA KING, Juan Francisco. Mujeres hispanas en la conquista del Nuevo Mundo: a la vanguardia de los acontecimientos. Revista de Estudios Hispánicos. 1995, n. 22, pp. 185-204.

MAURA KING, Juan Francisco. Mujeres hispanolusas en la expansión ultramarina de los siglos XV y XVI. Cuadernos Hispanoamericanos. 2015, n. 781-782, pp. 423. 
MAURA KING, Juan Francisco. Señoras y esclavas blancas en las Américas: Isabel de Bobadilla y su esclava Isabel. Cuadernos Hispanoamericanos. 2014, n. 769770, pp. 78-88.

MIGDEN SOCOLOW, Susan. The merchants of Buenos Aires 1778-1810. Family and commerce. Cambridge University Press, 1978.

MIRA CABALLOS, Esteban. Bancarrota y América: flujo y reflujo en una tierra de frontera. Badajoz: Junta de Extremadura-Consejería de Cultura, 2003.

MIRA CABALLOS, Esteban. Los prohibidos en la emigración a América (1492-1550). Estudios de historia social y económica de América. 1995, n. 12, pp. 37-54.

MONZÓN PERDOMO, María Eugenia. Ni solteras, ni casadas, ni viudas... Las mujeres ante la emigración masculina a América (siglos XVIII-XIX). En: GRIMALDI PEÑA, Isabel (ed.). XX Coloquio de Historia Canario-Americana. Cabildo de Gran Canaria, 2014, pp. 1015-1025.

MÖRNER, Magnus. La emigración española al Nuevo Mundo antes de 1810: un informe del estado de la Investigación. Anuario de Estudios Americanos.1975, n. 32, pp. 43-131.

MÖRNER, Magnus. Migraciones a Hispanoamérica durante la época colonial. Suplemento de Anuario de Estudios Americanos. 1991, vol. 48, n. 2, pp. 3-26.

MUÑOZ GARCÍA, María José. La condición jurídica de la mujer casada en Indias. Anuario de la Facultad de Derecho de la Universidad de Extremadura. 1991, n. 9, pp. 455-476.

NARBONA CARRIÓN, María Dolores. Anne Bradstreet (1612-1672): La cara femenina de los primeros viajes al Continente Americano. (S. XVII). En: GUARDIA, Sara Beatriz (coord.). Viajeras entre dos mundos. Dourados: Universidade Federal da Grande Dourados, 2012, pp. 81-103.

NAVARRO BONILLA, Diego. Del corazón a la pluma archivos y papeles privados femeninos en la Edad Moderna. Salamanca: Ediciones Universidad de Salamanca, 2004.

NAVARRO BONILLA, Diego. Sentir por escrito hacia 1650: cartas, billetes y lugares de memoria. En: TAUSIET CARLÉS, María y AMELANG, James S. (coords.). Accidentes del alma: las emociones en la Edad Moderna. Madrid: Abada, 2009, pp. 229-254.

NEASHAM, V. Aubrey. Spain's Emigrants to the New World 1492-1592. The Hispanic American Historical Review. 1939, vol. 19, n. 2, pp. 147-160.

ORTEGA MARTínEZ, Ana María. Mujeres españolas en la conquista de México. México: Vargas Rea, 1945. 
O'SULLIVAN-BEARE, Nancy. Las mujeres de los conquistadores. Madrid: Compañía Bibliográfica Española, 1956.

OTS CAPDEQUÍ, José María. Bosquejo histórico de los derechos de la mujer en la legislación de Indias. Madrid: Reus, 1920.

OTS CAPDEQUÍ, José María. El sexo como circunstancia modificativa de la capacidad jurídica en nuestra legislación de Indias. AHDE. 1930, n. 7, pp. 311380.

OTTE, Enrique. Cartas privadas de emigrantes a Indias, 1540-1616. Sevilla: V Centenario, D.L., 1988.

OTTE, Enrique. Cartas privadas de Puebla del siglo XVI. Jahrbuch für Geschichte Lateinamerikas = Anuario de Historia de América Latina (JbLA). 1966, n. 3, pp. 10-87.

OTTE, Enrique. Die europäischen Siedler und die Probleme der Neuen Welt. Jahrbuch für Geschichte Lateinamerikas = Anuario de Historia de América Latina (JbLA). 1969, n. 6, pp. 1-40.

OTTE, Enrique. La mujer de Indias en el siglo XVI. En: MORALES PADRÓN, Francisco (coord.). XIII Coloquio de Historia Canario-Americana; VIII Congreso Internacional de Historia de América (AEA) (1998). Cabildo de Gran Canaria, 2000, pp. 1493-1505.

OTTE, Enrique. Nueve cartas de Diego de Ordás. Historia Mexicana. 1964, vol. 14, n. 1, pp. 102-130.

PAREJA ORTIZ, María del Carmen. Aproximación a la mujer a través de los bienes de difuntos. Gades. 1992, n. 20, pp. 221-236.

PAREJA ORTIZ, María del Carmen. Aspectos de la vida cotidiana de mujeres de Huelva en las Indias: relación entre Lepe y América. Siglo XVI. En: TORRES RAMÍREZ, Bibiano (coord.). Huelva y América: actas de las XI Jornadas de Andalucía y América, Universidad de Santa María de la Rábida, marzo-1992. Vol. 1. Huelva: Diputación Provincial de Huelva, 1993, pp. 361-385.

PAREJA ORTIZ, María del Carmen. Las cartas de familia y la vida cotidiana de la mujer en Indias. En: AA. VV. Andalucía y América. Actas del Il Congreso de Historia de Andalucía, Córdoba 1991. Córdoba: Consejería de Cultura y Medio Ambiente, 1994, pp. 105-116.

PAREJA ORTIZ, María del Carmen. Nueva visión de la mujer española en Indias aspectos profesionales. En: SARABIA VIEJO, María Justina (coord.). Europa e Iberoamérica, cinco siglos de intercambios: actas. Vol. I. Sevilla: Junta de Andalucía, Consejería de Cultura, 1992, pp. 405-422. 
PAREJA ORTIZ, María del Carmen. Presencia de la mujer sevillana en Indias: vida cotidiana. Sevilla: Diputación Provincial, 1994.

PAREJA ORTIZ, María del Carmen. Vida cotidiana de María de Morales: una portuense en México en el siglo XVI. Revista de historia de El Puerto. 1991, n. 6, pp. 33-52.

PASCUA SÁNCHEZ, María José de la. "A la sombra" de hombres ausentes: mujeres malcasadas en el mundo hispánico del setecientos. Studia Historica. Historia Moderna. 2016, vol. 38, n. 2, pp. 237-285.

PASCUA SÁNCHEZ, María José de la. La cara oculta del sueño indiano: mujeres abandonadas en el Cádiz de la Carrera de Indias. Chronica nova: Revista de Historia Moderna de la Universidad de Granada. 1993-1994, n. 21, pp. 441-468.

PASCUA SÁNCHEZ, María José de la. La escritura privada y la representación de las emociones. En: BOLUFER PERUGA, Mónica; BLUTRACH JELÍN, Carolina y GOMIS COLOMA, Juan (coord.). Educar los sentimientos y las costumbres: una mirada desde la historia. Zaragoza: Institución Fernando el Católico (CSIC), 2014, pp. 81-108.

PASCUA SÁNCHEZ, María José de la. Las relaciones familiares: historias de amor y conflicto. En: MORANT DEUSA, Isabel (coord.). Historia de las mujeres en España y América Latina. Vol. 2. Madrid: Cátedra, 2005, pp. 287-316.

PASCUA SÁNCHEZ, María José de la. Mujeres solas: historias de amor y de abandono en el mundo hispánico. Málaga: Servicio de Publicaciones, Centro de Ediciones de la Diputación de Málaga, 1998.

PEREDA LÓPEZ, Ángela. La emigración burgalesa a América: durante el siglo XVI. Burgos: Caja de Burgos, 1999.

PÉREZ BUSTAMANTE, Ciriaco. Las regiones españolas y la población de América (1509-1534). Revista de Indias. 1941, n. 6, pp. 81-120.

PÉREZ MURILLO, María Dolores. El rol de lo femenino en las cartas de emigrantes de la época colonial. Dos puntas, 2015, n. 11, pp. 79-102.

PETRUCCI, Armando. Escribir cartas, una historia milenaria. Buenos Aires: Ediciones Ampersand, 2018.

POSKA, Allyson. Campesinas transatlánticas Las mujeres y la migración en el imperio español a finales del siglo XVIII. Nuevo Mundo. Mundos Nuevos. 2012, n. 12.

PRESTA, Ana María. Estados alterados. Matrimonio y vida maridable en charcas temprano-colonial. Población y sociedad. Ene./Jun. 2011, vol. 18, n. 1, pp. 17105. 
PULIDO BUENO, Idelfonso. Algunas notas sobre alistamientos de vecinos de Huelva en las Armadas de Indias a fines del siglo XVI. En: SOLANO PÉREZ-LILA, Francisco de Paula y PINO DÍAZ, Fermín del (coord.). América y la España del siglo XVI. Madrid: Consejo Superior de Investigaciones Científicas, 1982, pp. 147-159.

PUMAR MARTÍNEZ, Carmen. Españolas en Indias: mujeres-soldados, adelantadas y gobernadoras. Madrid: Anaya, 1988.

PURROY Y TURRILLAS, Carmen. La mujer navarra. Un caso excepcional en la emigración a América. En: MORALES PADRÓN, Francisco (coord.). XIII Coloquio de Historia Canario-Americana; VIII Congreso Internacional de Historia de América (AEA) (1998). Cabildo de Gran Canaria, 2000, pp. 1174-1185.

REY CASTELAO, Ofelia y TURNES MENJUTO, Ricardo. La emigración a América en la cuenca media del Ulla: un ejemplo de análisis comarcal. Revista da Comisión Galega do Quinto Centenario. 1989, n. 4, pp. 177-222.

REY CASTELAO, Ofelia. Las migraciones femeninas de Antiguo Régimen en su contexto europeo. En: HERNÁNDEZ BORGE, Julio y GONZÁLEZ LOPO, Domingo L. (coords.). Mujer y emigración una perspectiva plural: actas del Coloquio Internacional, Santiago de Compostela, 23-24 de noviembre de 2006. Universidad de Santiago de Compostela, Servicio de Publicaciones, 2008, pp. 39-68.

RODRÍGUEZ LORENZO, Sergio Manuel. El contrato de pasaje en la Carrera de Indias (1561-1622). Historia Mexicana. 2017, vol. 66, n. 3, pp. 1479-1571.

RODRÍGUEZ MENDOZA, Félix. La emigración del noroeste de Tenerife a América durante 1750-1830 [tesis doctoral]. Universidad de La Laguna, 2004.

ROSENBLAT, Ángel. Base del español de América: Nivel social y cultural de los conquistadores y pobladores. Revista de Indias. 1971, vol. XXXI, n. 125-126, pp. 13-75.

RUBIO MAÑÉ, Jorge Ignacio. Gente de España en la ciudad de México año de 1689. México: Archivo General de la Nación, 1966.

RUEDA HERNANZ, Germán y SOLDEVILLA ORIA, Consuelo. Españoles emigrantes en América (siglos XVI-XX). Madrid: Arco, 2000.

RUEDA RAMÍREZ, Pedro José. El control inquisitorial del libro enviado a América en la Sevilla del siglo XVII. En: PEÑA DÍAZ, Manuel; RUIZ PÉREZ, Pedro y SOLANA PUJALTE, Julián (coords.). La cultura del libro en la Edad Moderna: Andalucía y América. Universidad de Córdoba, Servicio de Publicaciones, 2001, pp. 255-270. 
RUEDA RAMÍREZ, Pedro José. Negocio e intercambio cultural: el comercio de libros con América en la carrera de Indias (siglo XVII). Sevilla: Secretariado de Publicaciones de la Universidad de Sevilla, 2005.

SAINZ VARELA, José Antonio. Los Pasajeros a Indias. Tábula: revista de archivos de Castilla y León. 2006, n. 9, pp. 11-72.

SÁNCHEZ FONNSECA, Ana (coord.). No fueron solos. Mujeres en la conquista y colonización de América. Ministerio de Defensa, 2012.

SÁNCHEZ RUBIO, Rocío y TESTÓN NÚÑEZ, Isabel. "Fingiendo llamarse... para no ser conocido": cambios nominales y emigración a Indias, siglos XVI-XVIII. Norba. Revista de Historia. 2008, n. 21, pp. 213-239.

SÁNCHEZ RUBIO, Rocío y TESTÓN NÚÑEZ, Isabel. "Nere Andrea, beti memorien daukedana". Amores y desamores de ultramar en el siglo XVIII. En: LARRAZA MICHELTORENA, María del Mar (coord.). Navarra y el Nuevo Mundo. Pamplona: Mintzoa, D.L., 2016, pp. 77-96.

SÁNCHEZ RUBIO, Rocío y TESTÓN NÚÑEZ, Isabel. "Por mares de olvidos". Correspondencia privada e Inquisición en Nueva España. Siglos XVI-XVIII. En: VIEIRA, Alberto [et al.] (coords.). Escritas das movilidades. Funchal (Madeira): Secretaria Regional de Educação e Cultura; Centro de Estudos de História do Atlântico, 2011, pp. 46-80.

SÁNCHEZ RUBIO, Rocío y TESTÓN NÚÑEZ, Isabel. El hilo que une. Las relaciones epistolares entre el Viejo y el Nuevo Mundo (siglos XVI-XVIII). Cáceres: Editora Regional, 1999.

SÁNCHEZ RUBIO, Rocío y TESTÓN NÚÑEZ, Isabel. Lazos de tinta, lazos de sangre. Cartas privadas entre el Nuevo y el Viejo Mundo (siglos XVI-XVIII). Universidad de Extremadura, 2014.

SÁNCHEZ RUBIO, Rocío y TESTÓN NÚÑEZ, Isabel. Mujeres abandonadas. Mujeres olvidadas. Cuadernos de Historia Moderna. 1997, n. 19, pp. 91-120.

SÁNCHEZ RUBIO, Rocío. La emigración extremeña al Nuevo Mundo: exclusiones voluntarias y forzosas de un pueblo periférico en el siglo XVI. Badajoz: Siruela, D.L. 1993.

SÁNCHEZ-ALBORNOZ, Nicolás y LLORDÉN MIÑAMBRES, Moisés. Migraciones iberoamericanas: reflexiones sobre economía, política y sociedad. Colombres, Asturias: Fundación Archivo de Indianos, 2003.

SÁNCHEZ-ALBORNOZ, Nicolás. La emigración española a América en medio milenio: pautas sociales. Historia social. 2002, n. 42, pp. 41-58. 
SIERRA BLAS, Verónica. "Puentes de papel": apuntes sobre las escrituras de la emigración. Horizontes Antropológicos. 2004, vol. 10, n. 22, pp. 121-147.

SIXIREI PAREDES, Carlos. Andalucía y Galicia. Dos modelos de emigración regional a América. En: AA. VV. Encuentro de Latinoamericanistas Españoles: Viejas y nuevas alianzas entre América Latina y España. España: CEEIB, 2006, pp.184-194.

SOLANO PÉREZ-LILA, Francisco de Paula y PINO DÍAZ, Fermín del (coords.). América y la España del siglo XVI. Madrid: Consejo Superior de Investigaciones Científicas, 1982.

SOUTELO VÁZQUEZ, Raúl. El protagonismo de las mujeres en las redes migratorias familiares: una visión a través de las fuentes epistolares. En: LINNARES GIRAUT, Xosé Amancio (coord.). El protagonismo de la mujer en las corrientes migratorias españolas. Vigo: Grupo España Exterior, 2009, pp. 207230.

STANGL, Werner. Consideraciones metodológicas acerca de las cartas privadas de emigrantes españoles desde América, 1492-1824. El caso de las "cartas de llamada". Jahrbuch für Geschichte Lateinamerikas = Anuario de Historia de América Latina (JbLA). 2010, n. 47, pp. 11-35.

STANGL, Werner. Un cuarto de siglo con Cartas privadas de emigrantes a Indias. Prácticas y perspectivas de ediciones de cartas transatlánticas en el Imperio español. Anuario de Estudios Americanos. 2013, vol. 70, n. 2, pp. 703-736.

STANGL, Werner: Zwischen Authentizität und Fiktion. Die Korrespondenz spanischer Emigranten aus Amerika, 1492-1824. Colonia / Weimar / Viena, Böhlau, 2012.

TESTÓN NÚÑEZ, Isabel y SÁNCHEZ RUBIO, Rocío. "De todo he estado ignorante por no haber visto letra de vuestra merced". La correspondencia epistolar como vehículo de comunicación en la sociedad moderna. En: CASTELLANO, Juan Luis y LÓPEZ-GUADALUPE MUÑOZ, Miguel Luis (coords.). Homenaje a Antonio Domínguez Ortiz. Vol. 2. Universidad de Granada; Junta de Andalucía, Consejería de Innovación, Ciencia y Empresa, 2008, pp. 771-778.

TESTÓN NÚÑEZ, Isabel y SÁNCHEZ RUBIO, Rocío. "Para hacer la raya enviamos un sobrino": el papel de la familia y el parentesco en las relaciones de la América española (siglo XVI)". En: SALINERO, Gregorio (coord.). Mezclado y sospechoso: movilidad e identidades, España y América (siglos XVI-XVIII): coloquio internacional (29-31 de mayo de 2000). Madrid: Casa Velázquez, 2005, pp. 91-120.

TESTÓN NÚÑEZ, Isabel y SÁNCHEZ RUBIO, Rocío. "Quien quiere, tarde olvida": cartas privadas de familias extremeñas entre España y América, siglos XVIXVIII. En: CASTILLO GÓMEZ, Antonio y SIERRA BLAS, Verónica (dirs.). CartasLettres-Lettere: discursos, prácticas y representaciones epistolares (siglos XIV- 
XX). Universidad de Alcalá, Servicio de Publicaciones, 2014, pp. 419-443.

TESTÓN NÚÑEZ, Isabel y SÁNCHEZ RUBIO, Rocío. A casa hecha y a mesa puesta: la función del parentesco, la amistad y el paisanaje en la emigración española al Nuevo Mundo. Siglo XVI. Rábida. 2002, n. 21, pp. 17-34.

TESTÓN NÚÑEZ, Isabel y SÁNCHEZ RUBIO, Rocío. Identidad fingida y migraciones atlánticas (siglos XVI-XVIII). En: SALINERO, Gregorio y TESTÓN NÚÑEZ, Isabel (eds.). Un juego de engaños: movilidad, nombres y apellidos en los siglos XV a XVIII. Madrid: Casa Velázquez, 2010, pp. 87-102.

TESTÓN NÚÑEZ, Isabel; HERNÁNDEZ BERMEJO, María Ángeles y SANTILLANA PÉREZ, Mercedes. El contexto familiar de la emigración extremeña a Indias en el siglo XVI. En: EIRAS ROEL, Antonio (coord.). La Emigración española a Ultramar, 1492-1914. Asociación de Historia Moderna; Ediciones Tabapress, 1991, pp. 245-256.

USUNÁRIZ GARAYOA, Jesús María. "Agur. Acaso, hasta el cielo": cartas de emigrantes vasco-navarros en Indias y sus lazos con el hogar (siglo XVIII). En: ARELLANO AYUSO, Ignacio (coord.). Modelos de vida y cultura en la Navarra de la modernidad temprana. Madrid: Instituto de Estudios Auriseculares (IDEA), 2016, pp. 365-383.

USUNÁRIZ GARAYOA, Jesús María. Cartas de amor y cartas de emigrantes como prueba judicial en España (siglos XVI-XVIII). Hispanic Research Journal: Iberian and Latin American Studies. 2015, vol. 16, n. 4, pp. 296-310.

USUNÁRIZ GARAYOA, Jesús María. Palabras de amor en el mundo hispánico: emociones y sentimientos en la correspondencia privada del Siglo de Oro. En: MARTÍNEZ PASAMAR, Concepción y TABERNERO SALA, Cristina (coord.). Por seso e por maestría: homenaje a la profesora Carmen Saralegui. Universidad de Navarra, Ediciones Universidad de Navarra, 2012, pp. 555-576.

USUNÁRIZ GARAYOA, Jesús María. Una visión de la América del siglo XVIII: correspondencia de emigrantes guipuzcoanos y navarros. Madrid: MAPFRE, 1992.

VILLAFAÑE, María José. La mujer española en la conquista y colonización de América. Cuadernos Hispanoamericanos. 1964, n. 175-176, pp. 125-142.

VIVES, Pedro A.; VEGA, Pepa y OYAMBURU, Jesús (coord.). Historia general de la emigración española a lberoamérica. Madrid: Historia 16, D.L. 1992.

ZAVALA DE COSÍO, María Eugenia y ROZÉE GÓMEZ, Virginie (coords.). El género en movimiento: Familias y migraciones. México D.F.: Colegio de México, 2014. 